\title{
Üstün Yetenekli Öğrencilere Yönelik Değerler Eğitiminde Yaratıcı Drama Yönteminin Kullanılması: Adalet Değeri Örneğii
}

\section{The Use of Creative Drama Method in the Teaching of Values of Gifted Children: The Case of Justice Value}

Ayşegül Oğuz Namdar ${ }^{* *} K_{\text {Kemal Akbayrak }}^{* * *}$

- Gelis Tarihi: 22.11.2018 • Kabul Tarihi: 19.03.2019 • Yayın Tarihi: 02.07.2019

\section{$\ddot{O} z$}

$\mathrm{Bu}$ araştırma üstün yetenekli öğrencilere verilecek değerler eğitiminde yaratıcı drama yönteminin sınanması amacıyla yapılmıştır. Araştırmanın çalışma grubunu Doğu Karadeniz Bölgesinde bulunan bir bilim ve sanat merkezinde destek eğitimi alan 3.sınıf seviyesindeki 8 öğrenci oluşturmaktadır. Araştırma üstün yetenekli öğrencilere 5 hafta süreyle toplamda 10 ders saatinden oluşan yaratıcı drama ile yapılandırılmış adalet eğitimi uygulamaları ile sınırlandırılmıştır. Uygulama öncesi ve sonrasında öğrencilerde adalet değerine ilişkin meydana gelen değişiklikler çeşitli nitel ölçme araçları kullanılarak belirlenmiş, elde edilen veriler içerik analizine ve betimsel analize tabi tutulmuştur. Araştırma sonucunda üstün yetenekli öğrencilerin verilen eğitimden sonra adalet kavramına ilişkin kavram yanılgılarının azaldığı, adalet kavramını somut örneklerle açıklayabildikleri görülmüştür.

Anahtar sözcükler: üstün yetenekli öğrenciler, değerler eğitimi, adalet değeri, yaratıcı drama

Atıf:

Namdar, A.O., ve Akbayrak, K. (2019). Üstün yetenekli öğrencilere yönelik değerler eğitiminde yaratıcı drama yönteminin kullanılması: Adalet değeri örneği. Pamukkale Üniversitesi Ĕ̆itim Fakültesi Dergisi, 47, 59-87. doi: 10.9779/pauefd.486641

\footnotetext{
* Bu araştırmanın bir bölümü 5. Uluslararası Üstün Yetenekliler ve Eğitimi Kongresinde (ÜYEK 2018) sözlü bildiri olarak sunulmuştur.

** Doç. Dr., Recep Tayyip Erdoğan Üniversitesi Eğitim Fakültesi, ORCID NO: 0000-0002-6853-8507 aysegul.oguz@erdogan.edu.tr

*** Öğretmen, Fatma-Nuri Erkan Bilim ve Sanat Merkezi, ORCID NO: 0000-0003-2390-9703 kemalakbayrak87@gmail.com
} 


\begin{abstract}
This research was carried out to test the creative drama method in values education for gifted students. The study group consists of 8 students attending the 3rd grade in a science and art center located in the Eastern Black Sea Region. The research is restricted to educational practices planned with creative drama for 10 hours across 5 weeks for teaching the idea of justice to gifted students. Changes in the students' perceived value of justice after the implementation were measured using various qualitative measurement tools, and the obtained data were subjected to content analysis and descriptive analysis. As a result, it was found out that misconceptions of the gifted students decreased and they were able to explain the concept of justice with concrete examples.
\end{abstract}

Keywords: gifted children, value education, justice, creative drama

\title{
Cited:
}

Namdar, A.O., \& Akbayrak, K. (2019). The use of creative drama method in the teaching of values of gifted children: The case of justice value. Pamukkale Üniversitesi Eğitim Fakültesi Dergisi, 47, 59-87. doi: 10.9779/pauefd.486641 


\section{Giriş}

Özel eğitim, özel gereksinimi olan bireyler için yetiştirilmiş özel personel ve geliştirilmiş özel öğretim programları ile özel ortamlarda yürütülen faaliyetler bütünüdür. Özel eğitim tanımı ve kapsamı itibari ile yalnızca fiziksel ve zihinsel engeli ya da öğrenme güçlüğü olan çocuklar için değildir. Üstün yetenekli çocuklar da özel eğitim kapsamı içerisinde değerlendirilmektedir. Üstün yetenekli çocuklar da mümkün olan en erken yaşta tanılanmalı ve özel eğitim hizmetlerine ulaşmaları sağlanmalıdır. Üstün yetenekli çocuk tanımı ile ilgili alan yazında farklı görüşler ortaya atılmıştır. Sousa'ya (2003) göre bunun iki nedeni vardır. İlki araştırmacıların üstünlük alan ve yeteneklerine bakış açılarındaki farklılık, ikincisi farklı kültürlerin farklı özelliklere sahip olmasıdır. Renzulli (2000) üstün bireyleri birbiriyle etkileşim içinde olan üç özellik kümesinden (genel-özel yetenek, yaratıc1lık, motivasyon) birinde akranlarından \% 98 oranında yüksek, her birinde akranlarından $\% 85$ oranında yüksek performans gösterebilenler olarak kabul etmiştir. Clark (1997) ise üstün yetenekli çocukları seçkin yetenekleri ve yüksek düzeyde iş yapma yeterlilikleri nedeniyle diğerlerinden ayırmıştır. Maker (2003), üstün yetenekliliğin karmaşık problemleri çözme yeteneği olduğunu öne sürmektedir. Bir başka araştırmada "teknik olarak 'üstün' çocuk bir akademik başarı testinde veya zekâ testinde yüksek puan alan ve tamamen veya kısmen kalıtımsal yeteneği olan çocuklardır" (Feldhusen ve Jarwan, 2000) tanımı yer almaktadır. Steiner ve diğerlerine (2003) göre, üstün yetenekli çocuklar ortalama yeteneğe sahip akranlarına göre birçok açıdan daha farklıdırlar. Tüm bunları dikkate alarak üstün yetenekli çocukları akranlarına oranla bilişsel, duyuşsal ve devinişsel olarak daha üst düzey performans gösteren çocuklar olarak ele alabiliriz.

Üstün yetenekli çocukların eğitimi için tüm dünyada olduğu gibi Türkiye'de de uzun yıllardır çalışmalar yapılmaktadır. Milli Eğitim Bakanlığınca 1993 yılında üstün yetenekli öğrencilere yönelik normal program ve müfredatın dışında eğitim verilmesi için bir dizi proje gerçekleştirilmiş ve Bilim ve Sanat Merkezleri adı altında yetenek geliştirme merkezleri kurulmuştur (Gökdere ve Çepni, 2005). 2018 yılı itibari ile 81 ilin tamamında en az bir bilim ve sanat merkezi üstün yetenekli öğrencilere farklılaştırılmış ve zenginleştirilmiş eğitimler vermektedir. Kuruluş tarihi eski olmasına rağmen, içerik geliştirme faaliyetleri son birkaç yılda merkezlerde görevli öğretmenler ve bu öğretmenler içinden seçilen koordinatörlerce, alan uzmanı akademisyenlerin de danışmanlığı ile sürdürülmektedir. $\mathrm{Bu}$ araştırmanın çalışma grubunu oluşturan üstün yetenekli öğrenciler de 2017-2018 eğitim-öğretim yılında Doğu Karadeniz Bölgesinde bir bilim ve sanat merkezinde destek eğitimi alan öğrencilerden oluşmaktadır.

Renzulli ve Reis (1985) ortalamanın üzerinde bir yetenek, yaratıcı düşünme ve sorumluluk bilincinin birleşimi olarak tanımlanan üstün yetenekli bireylerin eğitiminin normal bir eğitim süreci ile gerçekleştirilemeyeceğini ifade etmektedir. Alanyazın incelendiğinde üstün yetenekli öğrenciler ile ilgili yapılan pek çok araştırmanın (Çepni ve Gökdere, 2002; Dorhout, 1983; Feldhusen, 1997; Hansen ve Feldhusen, 1994; Wood ve Feldhusen, 1996) olduğu görülmektedir. Çoğu araştırmada, üstün ve özel yetenekli öğrencilerin farklı eğitsel ihtiyaçları olduğu ve bu nedenle normal öğretim programlarına ek olarak ilgi ve yeteneklerini destekleyecek alternatif öğrenme ortamlarına gereksinim duydukları belirtilmektedir (Fiedler, Lange \& Wibebrenner, 2002; Renzulli, 1999). Bilim ve Sanat Merkezleri bu bakış açısı ile kurulmuş eğitim kurumları olma özelliğindedir. Renzulli ve Reis (1985) ortalamanın üzerinde 
bir yetenek, yaratıcı düşünme ve sorumluluk bilincinin birleşimi olarak tanımlanan üstün yetenekli bireylerin eğitiminin normal bir eğitim süreci ile gerçekleştirilemeyeceğini ifade etmektedir. Bu nedenlerle Bilim ve Sanat Merkezlerinde verilen eğitimin hem içerik hem de yöntem olarak normal okullardan farklı olması gerekmektedir. George (2003)'e göre üstün yetenekli öğrenciler için uygulanacak programlarda, öğretmenler özel çalışmalarda öğrencilerin sıkılmasına sebep olacak uygulamalardan uzak durmalıdır. Bu bakımdan araştırmanın üstün yeteneklilere verilecek değerler eğitimi için bir yöntem olarak yaratıcı dramanın etkililiğini incelemesi hem alanyazına hem de Bilim ve Sanat Merkezlerinde görev yapan öğretmenlere fayda sağlayacağı düşünülmektedir.

Üstün yetenekli öğrencilerle yaratıcı drama yönteminin kullanıldığı araştırmalara bakıldığında; ahlaki yargı düzeylerinin incelenmesi (Bencik Kangal ve Arı, 2013), problem çözme becerilerinin incelenmesi (Lewis, 1972), klasik edebiyat eserlerinin öğrenimine etkisi, (Winstead, 1997), yaratıcılık gelişimine etkisi (Halpen ve diğ, 1974; Wu, 2008), dil gelişimine etkisi (Stewing ve Vail, 1985), düşünme becerilerinin gelişimine etkisi (Gangi, 1990), liderlik becerilerinin gelişimine etkisi (Hansel, 1991), yaratıcllıklarına etkisi (Ihlamur ve Aykaç, 2016) gibi konuların çalışıldığı görülmektedir. Alanyazın incelendiğinde üstün yetenekli öğrencilerin eğitiminde farklı konu alanlarında yaratıcı dramanın kullanıldığı ve etkili sonuçlar alındığı görülmektedir. Gönen ve Dalkılıç’a (2003) göre yaratıcı drama, çocuğun; özgüven duygusunun gelişmesini, empati yaparak çok yönlü düşünebilmesini, işbirliği, dayanışma ve paylaşma duygusunun gelişmesini, kendisini ifade edebilmesini, öğrendiği bilgilerin kalıcılığını, değişik yaşantıları tanımasını, eğitim ve öğretimde aktif rol almasını, rahatlamasını, oyun ihtiyacını gidermesi, sorumluluk duygusunun gelişmesini, yaratıcı olmasını, araştırma istek ve duygusunun gelişmesini, farklı bakış açılarına sahip olmasını, eleştirmeyi ve tartışmayı öğrenmesini sağlamaktadır. Bu nedenle üstün yetenekli öğrencilerin değerler eğitiminde de yaratıcı drama yöntemiyle etkili sonuçlar alınabileceği düşünülmektedir.

Üstün yetenekli öğrencilerin ailelerince fark edilmelerini sağlayan en önemli özellikleri gelişmiş bilişsel ve devinişsel becerileridir. Erken konuşma, erken okuma-yazma, güzel resim yapma, ritim tutma gibi gözlemlenebilir belirgin davranışlar ailelerce kolaylıkla fark edilir. Ancak yapılan araştırmalar üstün yetenekli öğrencilerin sadece bilişsel ve devinişsel değil duyuşsal anlamda da akranlarından üstün oldukları yönündedir. Üstün yetenekli öğrencilerin akranlarından farklı olan özelliklerinin başında adil olmak, eşitlik, hakkı gözetmek, sorunlar karşısında duyarlı olmak gelmektedir (Çetinkaya ve Döner, 2013; Davaslıgil, 2004). Bu bakımdan üstün yetenekli öğrencileri eğitirken yalnızca bilişsel ve devinişsel gelişimlerini desteklemek yeterli değildir. Duyuşsal anlamda da desteklenmeye ihtiyaçları vardır. Bu da üstün yetenekli öğrencilere değerler eğitiminin de verilmesini gerekli kılmaktadır. Gerek öğrenme hızı gerekse de öğrenme stili olarak farklı olan üstün yetenekli öğrencilere verilecek değerler eğitiminin normal öğrencilere verilen değerler eğitiminden farklı olması gerekmektedir. Çetinkaya ve Döner'e (2013) göre üstün yetenekli öğrenciler toplumda yadırganan üstünlüğün getirmiş olduğu bireysel özelliklerinden dolayı bu anlamda özel bir eğitime ihtiyaç duymaktadırlar.

Yenilenen ilköğretim programında kök değerler; adalet, dostluk, dürüstlük, öz denetim, sabır, saygı, sevgi, sorumluluk, vatanseverlik, yardımseverlik olarak belirlenmiştir. Bu değerler, öğrenme öğretme sürecinde hem kendi başlarına, hem ilişkili olduğu alt değerlerle, hem de 
diğer kök değerlerle birlikte ele alınarak hayat bulacaktır (MEB, 2018). Yenilenen öğretim programları ile değerler eğitiminin daha ön planda olacağı görülmektedir. Araştırmada ele alınan adalet değeri de programda öncelikli değerler arasında yer almaktadır. Üstün yetenekli öğrenciler akranlarına oranla daha duygusal yapıdadırlar. Özbay ve Palancı'ya (2011) göre üstün yeteneklilerin incinebilirlik düzeyleri üstün yeteneklilik düzeylerine göre artış göstermektedir ve bu durum daha çok sosyal ve duygusal risk yaşamalarına neden olmaktadır. $\mathrm{Bu}$ duygusallıkları ve aşırı duyarlılıkları evde, okulda, sosyal çevrede gördükleri adaletsizliklere aşırı tepki vermelerine neden olabilmekte ve bu hak arama durumu yetişkinlerce davranış problemi olarak görülmektedir. Üstün yetenekli öğrencilerin taşıdıkları liderlik potansiyelleri (Renzulli ve diğ., 2002) dikkate alındığında, özellikle adalet kavramının onlar için daha önemli olduğu ortaya çıkmaktadır. Bilimde, sanatta, siyasette önderlik edecek üstün yetenekli kişilerin adil bireyler olarak yetiştirilmesi büyük önem taşımaktadır. Bu gerekçelerle araştırma adalet değeri üzerinden gerçekleştirilmiştir.

Bilişsel alanın bilgi basamağında sayılabilecek bazı öğrenmeler olmadan duyuşsal alandaki davranışlar gerçekleşmeyebilir (Erden ve Akman, 1995). Adalet kavramı ve diğer değer kavramları özellikle ilkokul düzeyi öğrenciler için anlaşılması güç kavramlardır ve çoğu zaman farklı kavramlarla karıştırılabilmektedir. Kavramların somutlaştırılmasında kullanılabilecek etkili öğretim yöntemlerinden bir tanesi de yaratıcı dramadır. Yaratıcı dramanın alanyazında yapılan pek çok tanımı vardır. Adıgüzel'e göre (2015) yaratıcı drama, tümel bir öğrenmeyi gerçekleştirebilecek özelliklere sahiptir, öğrenmede bilişsel, duyuşsal ve devinişsel gelişim alanlarının eş zamanlı olarak gerçekleştirilmesini kolaylaştırır ve öğrenmenin yaşantısal hale getirildiği uygulamalardan oluşur. San (1990) yaratıcı dramayı doğaçlama, rol oynama, tiyatro ya da drama tekniklerinden yararlanılarak, bir grup çalışması içinde, bireylerin, bir yaşantıyı, bir olayı, kimi zaman bir soyut kavramı ya da bir davranışı oyunsu süreçlerde anlamlandırması ve canlandırması olarak tanımlamaktadır. Üstündağ'a (1994) göre yaratıc1 drama; eğitim sürecinde oyunlarla geliştirilen bir etkinliktir ve bu özelliği ile eğitimin yaşamsal parçasıdır. McNaughton'a (2004) göre yaratıcı drama, bireyin iletişim ve karar verme becerilerinin gelişimine yardımcı olabilir ve arkadaşlarına yönelik duyarlılık kazanmasını sağlayabilir. Yaratıcı drama yöntemi ile yapılandırılmış dersler çocuklar tarafından beğenilmekte ve onlarda etkinliklere katılım isteği uyandırmaktadır. Yaratıcı dramanın bu özelliği öğrencilerin öğrenmeye gönüllü olmasını sağlamaktadır. Gökdere ve Çepni’nin (2003) araştırmasına göre değerlerin çocuklara zorlama ile kazandırılmaya çalışılması durumunda, öğrenciler bu zorlamaya olumsuz tepki gösterecektir ve belki de kazandırılmak istenen özelliğe tepki olarak zıt bir özellik kazanacaktır. Aynı araştırmada üstün yetenekli öğrencilere verilecek değerler eğitimi uygulamalarında öğretmenin rolü tanımlanırken, öğrencilerin aktif katılımlarını sağlamak, onlara rol model olmak, zaman ve içerik bakımından esnek olmak, öğrencilerin değerleri keşfetmesine rehberlik etmek gibi ifadeler yer almaktadır. Yaratıcı drama yönteminde yer alan birçok teknik, öğrencilerin ve öğretmenin (liderin) eğitim sürecinde eşit konumlarda olmasını sağlamaktadır. Süreçte ortadan kalkan statü farkı lider ile öğrenciler arasında daha samimi bir bağ kurulmasını sağlamaktadır. Bu durum kaygı düzeyini azaltmakta ve öğrencilerin öğrenmeye direnç göstermelerini önlemektedir. Bu bağlamda üstün yetenekli öğrencilere verilecek değerler eğitiminde yaratıcı drama yönteminin güçlü bir yöntem olduğu öngörülmektedir. Bu araştırmada 3.sınıfa devam eden üstün yetenekli öğrencilere yaratıcı drama 
yöntemiyle verilen "adalet" eğitiminin etkililiğinin incelenmesi için gerçekleştirilmiştir. Bu amaç doğrultusunda aşağıdaki sorulara yanıt aranmıştır.

1-Adalet kavramına ilişkin öğrencilerin yaptıkları tanımlarda ne gibi değişiklikler olmuştur?

2-Adalet kavramına ilişkin öğrencilerin yaptıkları çizimlerde ne gibi değişiklikler olmuştur?

3-Adalet, eşitlik ve hak kavramları ile ilgili öğrencilerin zihinlerinde çağrışan kelimelerde ne gibi değişiklikler olmuştur?

4-Adalet ve eşitlik kavramları hakkında öğrencilerin kavram yanılgıları ne düzeydedir, bu yanılgılar ne kadar düzeltilebilmiştir?

\section{Yöntem}

$\mathrm{Bu}$ araştırma nitel araştırma desenlerinden eylem araştırması yöntemi ile gerçekleştirilmiştir. Araştırmada eylem araştırması türlerinden biri olan "uygulama/karşılıklı işbirliği/tartışma odaklı eylem araştırması" yaklaşımı tercih edilmiştir. Araştırma problemi uygulayıcı ile araştırmacı işbirliği ile tespit edilmiştir. Bu yaklaşımın doğası gereği araştırmacı ve uygulayıcı bir araya gelerek uygulamada ortaya çıkabilecek olası sorunları, bu sorunlara neden olan olası nedenleri ve olası müdahale yollarını belirlerler. Bu model uygulamayı geliştirmeye yönelik olduğu için "uygulama odaklı eylem araştırması" olarak da adlandırılır (Yıldırım ve Şimşek, 2006; Yuladır ve Doğan, 2009). Çalışma üç temel aşamadan oluşmaktadır. Birinci aşamada araştırmanın problem durumu saptanmış ve gerekli alanyazın taraması yapılmıştır. Sonraki aşamada incelenen kaynaklardan yola çıkarak problemin çözümüne yönelik eylem planı geliştirilmiştir. Son aşamada belirlenen plan uygulanmış, uygulama sonucu elde edilen veriler analiz edilerek yorumlanmıştır.

Uygulama 6x5 metre ebatlarında kapalı bir sınıfta gerçekleştirilmiştir. Sınıf içerisinde her öğrencinin oturabileceği sandalye, grup çalışmasına uygun modüler masalar, yeterli düzeyde ses sistemi ve ısınma etkinliklerinin yapılabileceği serbest alan bulunmaktadır. Uygulamadan önce uygulama esnasında gerekli olabilecek tüm malzemeler temin edilmiştir. Uygulamanın yapılacağına ilişkin kurum yetkililerine ve öğrenci velilerine bilgi verilmiştir. Planlanan oturumları uygulayan kişi araştırma ekibinin üyesidir. Üstün yetenekli çocukların eğitiminde yaratıcı drama yönteminin kullanımı üzerine yüksek lisans çalışmalarını sürdürmektedir. Farklı ulusal projelerde ve eğitim kamplarında yaratıcı drama liderliği yapmıştır. Aynı zamanda çalışmanın gerçekleştirildiği Kurumda tam zamanlı sınıf öğretmeni olarak üç yıldır görev yapmaktadır. Araştırmacılardan birinin aynı kurumda görev yapıyor olması nedeniyle yasal özel izin alınmasına gerek duyulmamıştır. Uygulamada planlanan her oturumun görsel kaydı tutulmuş, uygulama esnasında dikkat çeken hususlar araştırmacı tarafından yazılı olarak kayıt altına alınmıştır. Uygulama her biri 2 ders saatinden $(40+40 \mathrm{dk})$ oluşan 5 oturum olarak gerçekleştirilmiştir. Her bir oturum için yaratıcı drama ile yapılandırılmış bir ders planı hazırlanmıştır. Adıgüzel'e (2015) göre drama dersinin yapılandırılmasında "Isınma/Hazırlık, Canlandırma, Değerlendirme/Tartışma" aşamaları izlenmelidir. Uygulama her hafta bir oturum olacak şekilde 5 haftada tamamlanmıştır. Uygulama öncesi ve sonrasında veri toplama araçları öğrencilere uygulanmıştır. Uygulamada yer alan oturumlara ilişkin detaylı bilgi Tablo 1' de gösterilmiştir. 
Tablo 1. Uygulamada Yer Alan Oturumlara İlişsin Kazanım ve Teknikler

\begin{tabular}{|c|c|c|c|}
\hline Oturum Başlı̆̆1 & Süre & Kazanım & $\begin{array}{l}\text { Kullanılan } \\
\text { Teknikler }\end{array}$ \\
\hline Mahkeme Salonu & $40+40 \mathrm{dk}$ & $\begin{array}{l}\text { Müziğin ritmine uygun dans eder. } \\
\text { Adaletin ne olduğunu açıklar. } \\
\text { Bir anlaşmazlık karşısında adaleti sağlamak } \\
\text { için çözüm önerisi sunar. } \\
\text { Mahkemelerin adaleti sağlamak için } \\
\text { kurulduğunu fark eder. }\end{array}$ & $\begin{array}{l}\text { Dans, } \\
\text { Doğaçlama, } \\
\text { Örnek Olay } \\
\text { İncelemesi, } \\
\text { Liderin Role } \\
\text { Girmesi. }\end{array}$ \\
\hline Adalet mi, Eşitlik mi? & $40+40 \mathrm{dk}$ & $\begin{array}{l}\text { Müziğin ritmine uygun dans eder. } \\
\text { Eşitliğin ne olduğunu açıklar. } \\
\text { Adaletsizliğe uğradığında neler hissettiğini } \\
\text { açıklar. } \\
\text { Eşitlik ve adalet arasındaki ilişkiyi fark eder. } \\
\text { Eşitlik ve adalet arasındaki farkı açıklar. } \\
\text { Bir problem durumunda adil çözümler üretir. }\end{array}$ & $\begin{array}{l}\text { Dans, Rol } \\
\text { Oynama, } \\
\text { Doğaçlama, } \\
\text { Örnek Olay } \\
\text { İncelemesi, } \\
\text { Liderin Role } \\
\text { Girmesi, Öykü } \\
\text { Tamamlama, } \\
\text { Dans Etme, } \\
\text { Rol Değiştirme }\end{array}$ \\
\hline Adil Paylaşım & $40+40 \mathrm{dk}$ & $\begin{array}{l}\text { Müziğin ritmine uygun dans eder. } \\
\text { Adil paylaşım yapar. }\end{array}$ & $\begin{array}{l}\text { Dans, Resim } \\
\text { Çizme }\end{array}$ \\
\hline Haklar ve Haksızlıklar & $40+40 \mathrm{dk}$ & $\begin{array}{l}\text { Müziğin ritmine uygun dans eder. } \\
\text { Haksızlığın ne olduğunu fark eder. } \\
\text { Haksızlığa uğradığında nasıl davrandığını } \\
\text { açıklar. } \\
\text { Haksızlıklar karşısında öfkesini nasıl kontrol } \\
\text { edeceğini fark eder. }\end{array}$ & $\begin{array}{l}\text { Dans, } \\
\text { Tekerleme, Rol } \\
\text { Oynama, } \\
\text { Hikâye/Olay } \\
\text { İnceleme, } \\
\text { Dans, } \\
\text { Canlandırma }\end{array}$ \\
\hline Adalet, Daha Çok Adalet & $40+40 \mathrm{dk}$ & $\begin{array}{l}\text { Müziğin ritmine uygun dans eder. } \\
\text { Verilen malzemeler ile çomak kukla hazırlar. } \\
\text { Adaletsizliğe örnek verir. } \\
\text { Her canlının adalete ihtiyacı olduğunu fark } \\
\text { eder. } \\
\text { Hayvanların da hakları olduğunu fark eder. }\end{array}$ & $\begin{array}{l}\text { Dans, Çomak } \\
\text { Kukla }\end{array}$ \\
\hline
\end{tabular}

\section{Araştırma Grubu}

Araştırmanın çalışma grubu 2017-2018 eğitim-öğretim yılında Doğu Karadeniz Bölgesinde bir Bilim ve Sanat Merkezinde destek eğitimi alan 3.sınıf düzeyindeki 8 üstün yetenekli öğrenciden oluşmaktadır. Araştırmaya katılan öğrencilerin cinsiyet dağılımı 4 kız, 4 erkek şeklindedir. 
Bilim ve Sanat Merkezlerinde destek eğitim programında öğrenci grupları 4-12 kişi olacak şekilde planlanmaktadır (MEB, 2018). Araştırma tek grup ile gerçekleştirildiği için öğrenci sayısı 8 ile sınırlı kalmıştır. Bu sayının da üstün yetenekli öğrenci grupları için normal olduğu söylenebilir.

\section{Veri Toplama Araçları}

Araştırma kapsamında nicel veri toplama araçlarından "çizim ve görüşme, kelime ilişkilendirme testi ve yarı yapılandırılmış görüşme formu kullanılmıştır. Ölçme araçları araştırmacılar tarafından geliştirilmiş, geliştirme ve uygulanma süreçleri ile ilgili ayrıntılı bilgi başlıklar altında sunulmuştur.

Çizim ve görüşme

$\mathrm{Bu}$ yöntem eğitim ve psikoloji araştırmalarında öğrencilerin duygu ve düşüncelerini ortaya çıkarması bakımından sık kullanılan etkin bir yöntemdir (Okyay, 2008). Yaratıcı drama ile yapılandırılmış adalet eğitimi öncesi ve sonrasında öğrencilere "Adalet deyince aklınıza neler geliyor?" odak sorusu sorulmuş, bu doğrultuda kavramla ilgili akıllarına gelenleri verilen A4 kâğıdı üzerine çizmeleri istenmiştir. Halmatov'a (2015) göre resim analizi çalışmalarında görüşmelerden elde edilen veriler kullanılırsa elde edilecek yargılar desteklenmiş olmaktadır.

\section{Kelime ilişsilendirme testi (KIT)}

KİT, öğrencilerin bilişsel yapısında yer alan kavramlar arasındaki ilişkiyi gözler önüne serebilen alternatif ölçme değerlendirme tekniklerinden birisidir (Bahar ve ark., 1999). Bu teknik alanyazında bilişsel yapıların ortaya konulması, kavram yanılgılarının tespiti, kavramsal değişimlerin belirlenmesi gibi çalışmalarda kullanılmıştır (Bahar ve ark., 1999; Cardellini ve Bahar, 2000; Bahar ve Özatl1, 2003; Ercan ve Taşdere, 2010; Nakiboğlu, 2008). Araştırma öncesi ortak özelliklere sahip beş öğrenci ile "adalet" kavramı üzerine bir KİT uygulamas1 gerçekleştirilmiş, bu uygulamada "adalet" kavramı en çok "eşitlik" ve "hak" kavramları ile ilişkilendirilmiştir. Bu pilot çalışma neticesinde araştırma grubu için uygulanacak KİT için her üç kavramın da (adalet, eşitlik, hak) bulunması gerektiğine karar verilmiştir.

\section{Yarı yapılandırılmış görüşme formu (YYGF)}

Özel bir konu ya da durumda derinlemesine yapılan araştırmalarda kullanılan YYGF anlaşılamayan konuların yeni bir soru ile tekrar açıklanması ile cevapların tamamlanması açısından avantajlıdır (Çepni, 2007). Araştırmada öğrencilerin adalet ve ilişkili kavramlarla ilgili görüşleri hakkında bilgi edinmek adına YYGF kullanılması uygun bulunmuştur. Adalet kavramının tanımı, önemi, adil insanlarda bulunması gereken özellikler, adalet ve eşitlik arasındaki ilişki ve yaşadığımız toplumun adil olup olmadığına ilişkin görüşleri hakkında bilgi toplamak amaçlı sorular araştırmacılar tarafından hazırlanmıştır.

\section{Verilerin Toplanması}

Araştırma grubuna her hafta bir oturum olacak şekilde 5 hafta süre ile yaratıcı drama ile yapılandırılmış adalet eğitimi verilmiştir. Uygulama öncesinde ve sonrasında veri toplama araçları öğrencilere uygulanmıştır. 
Çizim ve görüşme

Çizimler için bir süre sınırı konulmamış ve çizimlerde öğrencilerin birbirlerinden esinlenmemeleri için gerekli önlemler alınmıştır. Resimler A4 kâğıdı üzerine karakalem olacak şekilde yapılmıştır. Öğrencilerin yaptıkları çizimleri daha sonra ayrıntılı olarak anlatmaları sağlanmış ve araştırmacılar tarafından not edilmiştir. Görüşmeler bireysel olarak yapılmış, öğrencilerden kendini ifade etmekte zorlanan olmadığı görülmüştür. Her bir görüşme ortalama 5-7 dakika sürmüştür.

\section{Kelime ilişkilendirme testi (KITT)}

Test için "adalet, eşitlik ve hak" kavramları kullanılmıştır. Test öncesi KİT hakkında çocuklara bilgi verilmiş ve "kedi, köpek ve kuş" kelimeleri üzerinden örnek uygulamalar yapılmıştır. Zincirleme kelime yazmayı önlemek amaciyla her bir kavram tek bir sayfa üzerine alt alta 5 satır boyunca yazılmıştır. Her kelime yazımından sonra anahtar kelimeye dönülmezse son yazılan kelimenin çağrıştırdığı bir kelimeyi bir sonraki adıma yazma durumu olabilir ve bu durum testin amacı dışına çıkmasına neden olabilir (Bahar ve Özatlı, 2003). Alanyazında kelime ilişkilendirme testi kullanırken araştırmacıların her kavram için 30 saniye süreyi uygun gördükleri tespit edilmiştir (Bahar ve diğ., 1999; Bahar ve Özatlı, 2003). Çalışma grubunun ilkokul düzeyinde oluşu nedeniyle her bir kavram için 120 saniye süre uygun görülmüştür.

Yarı yapılandırılmış görüşme formu (YYGF)

Öğrencilerin adalet kavramına ilişkin var olan ön bilgilerinin ortaya konması ve uygulama sürecinin etkilerinin gözlenebilmesi için 5 sorudan oluşan YYGF kullanılmıştır. Sorular araştırmacılar tarafından hazırlanmış, anlaşılabilirliğinin kontrolü için çalışma grubu ile ortak özelliklere sahip beş öğrenciye okutulmuş ve gerekli düzeltmeler yapılmıştır. YYGF'de kullanılan sorular şu şekildedir:

1-Sence "Adalet" ne demektir? Yaptığın tanıma göre adil biri olduğunu düşünüyor musun?

2-Adil olmak neden önemlidir?

3-Adil biri olmak için nasıl davranmak gerekir?

4-Şimdiye kadar birine adaletsizlik yaptığını düşünüyor musun?

5-Sence adalet ve eşitlik arasında bir fark var mı?

6-Sence yaşadığımız yer/ülke adil bir yer mi? Neden?

$\mathrm{Bu}$ soruların sorulma amacı öğrencilerin adalet kavramına ilişkin kavram yanılgılarının fark edilmesi, adaletin ve adil olmanın önemine ilişkin görüşlerinin tespit edilmesi, adalet ve eşitlik arasında kurduğu ilişkinin keşfedilmesi ve yaşadığı yer/ülkenin adil olup olmadığı yönündeki görüşlerinin tespit edilmesidir.

\section{Verilerin Analizi}

Araştırmada elde edilen verilerin analizi için nitel veri analizi tekniklerinden betimsel analiz ve içerik analizi kullanılmıştır. Betimsel analiz, verileri okuyucuların anlayabileceği şekilde düzenleme işlemidir (Altunışık ve diğ., 2001). İçerik analizi, belli kuralları olan kodlamalarla, bir metnin önemli sözcüklerinin daha küçük içerikler şeklinde özetlendiği sistematik, yinelenebilir bir teknik olarak kabul edilmektedir (Büyüköztürk ve diğ., 2008). İçerik analizinde 
amaç, toplanan verileri açıklayabilecek kavramlara ve ilişkilere ulaşmaktır (Yıldırım ve Şimşek, 2006).

Çizim ve görüşme

Öğrencilerin "adalet” kavramına ilişkin yaptığı çizimlerde kullandıkları figürler kaydedilmiş ve frekans tablosu çıkarılmıştır. Öğrencilerin çizimlerini anlatmaları sağlanarak figürlerin yanlış yorumlanmasının önüne geçilmeye çalışılmıştır.

Kelime ilişkilendirme testi (KİT)

Kelime ilişkilendirme testi sonuçlarının analizi için anahtar kavramlara verilen cevap kelimeler ayrıntılı bir şekilde incelenmiştir. Hangi anahtar kavram için hangi kelimelerin yazıldığını göstermek için bir frekans tablosu oluşturulmuştur. Daha sonra bu frekans tablosu dikkate alınarak bir kavram ağı oluşturulmuştur. Kavram ağı oluşturulurken anahtar kavramlar ve cevap kelimeler arasındaki bağlantılar frekansa bağlı olarak farklı renkler kullanılarak gösterilmiştir. Kavram ağ tekniği dikkate alınmıştır. Ancak üstün yetenekli öğrenci grubu ile çalışıldığından dolay1 katılımcı sayısının azlığı nedeniyle kesme noktaları arasında bir boşluk bulunmamaktadır.

Yarı yapılandırılmış görüşme formu (YYGF)

Yarı yapılandırılmış görüşme formuna öğrencilerin verdiği yanıtların Microsoft Word yazı işleme programıyla dökümü alınmıştır. Elde edilen belge dikkatlice okunmuştur. Daha sonra öğrencilerin verdiği cevapların kodlaması yapılmıştır. Kodlama yapılırken öğrencilerin cevaplarında kullandıkları kelime ve kelime gruplarının kullanımına özen gösterilmiş, ancak yetersiz ifadelerin yer aldığı durumlarda araştırmacılar tarafından ifadeyi en iyi karşılayacak bir kod seçilmeye çalışılmıştır. Betimsel analizde ise sık sık öğrenci yanıtlarından çarpıcı olan ifadelerden doğrudan alıntılar yapılarak sunulmuştur. İçerik analizinde ise öğrenci yanıtlarından elde edilen kodların frekansları bulunarak yansıtılmıştır. Verilerin yorumlanması sürecinde her iki analiz de dikkate alınmıştır.

\section{Bulgular}

\section{Çizim ve Görüş̧melerden Elde Edilen Bulgular}

Öğrencilerden eğitimlerden önce ve sonra "adalet" kavramına ilişkin bir resim çizmeleri ve çizimlerini yorumlamaları istenmiştir. Öğrencilerin resimlerinde kullandıkları figürlerin frekans dağılımı yapılarak tablolaştırılmıştır. 
Tablo 2. Öğrencilerin Uygulama Öncesi ve Sonrası Yaptıkları Çizimlerde Kullandıkları Objelerin Tekrar Sıklıkları

\begin{tabular}{|c|c|c|c|c|c|}
\hline \multicolumn{3}{|l|}{ Uygulama Öncesi } & \multicolumn{3}{|l|}{ Uygulama Sonras1 } \\
\hline Çizilen Öğeler & $\mathrm{K} 1 \mathrm{z}$ & Erkek & Çizilen Öğeler & $\mathrm{K} 1 \mathrm{z}$ & Erkek \\
\hline Seçim Sandığ & & 1 & İnsan & 1 & 3 \\
\hline Zarf & & 1 & Terazi & & 2 \\
\hline İnsan & 3 & 2 & Avize & 2 & \\
\hline Terazi & & 2 & Çikolata & 1 & \\
\hline Yatak & & 1 & Kaynak Makinesi & & 1 \\
\hline Kalem & 1 & & Tornavida & & 1 \\
\hline Bulut & 1 & & Tekerlek & & 1 \\
\hline Güneş & 2 & & Tamir Anahtarı & & 1 \\
\hline Ağaç & 1 & & Araba & & 1 \\
\hline Paket & 1 & & Masa & & 1 \\
\hline Dağ & 1 & & Taş & 1 & \\
\hline Araba & & 1 & Metal Ağırlık & 1 & \\
\hline Tamir Anahtarı & & 1 & Bina & 1 & \\
\hline Bina & 1 & 1 & Çit & 1 & \\
\hline Kap1 & 1 & 1 & Pencere & 1 & \\
\hline Çatı & 1 & 1 & Kap1 & 1 & \\
\hline Polis & 1 & & Merdiven & 1 & \\
\hline Madeni Para & 1 & & & & \\
\hline Şeker & 1 & & & & \\
\hline Tanımlanamayan & 1 & & & & \\
\hline Yazi & 3 & 1 & & & \\
\hline
\end{tabular}


Uygulama öncesinde çizilen resimlerde adalet kavramını anlatmaya çalışırken öğrencilerin sık sık yazı yazmaya gereksinim duydukları, sonrasında ise sadece figürler ile adalet kavramını anlatmaya çalıştıkları gözlenmiştir. Uygulama öncesi ve sonrasında "adalet" kavramı üzerine öğrencilerin çizdiği resimlerden örnekler ve yapılan yorumlar şu şekildedir.

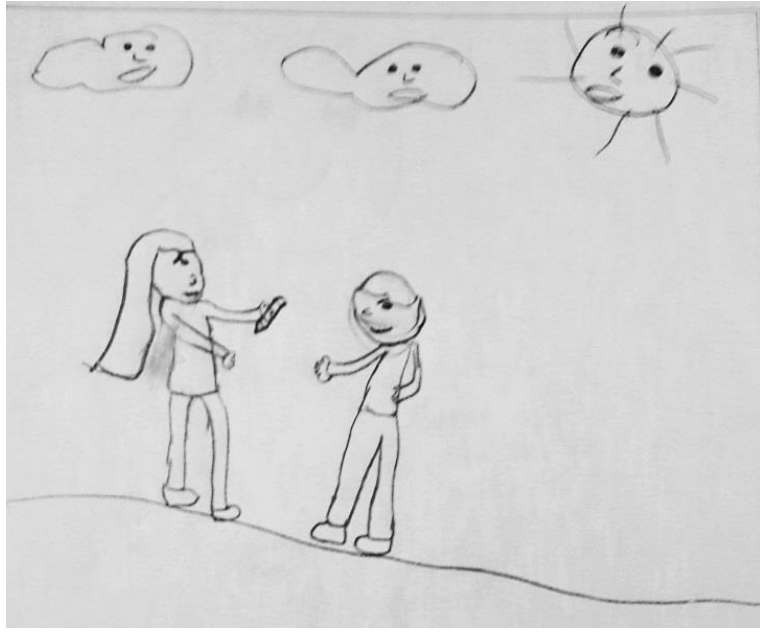

Uygulama öncesi

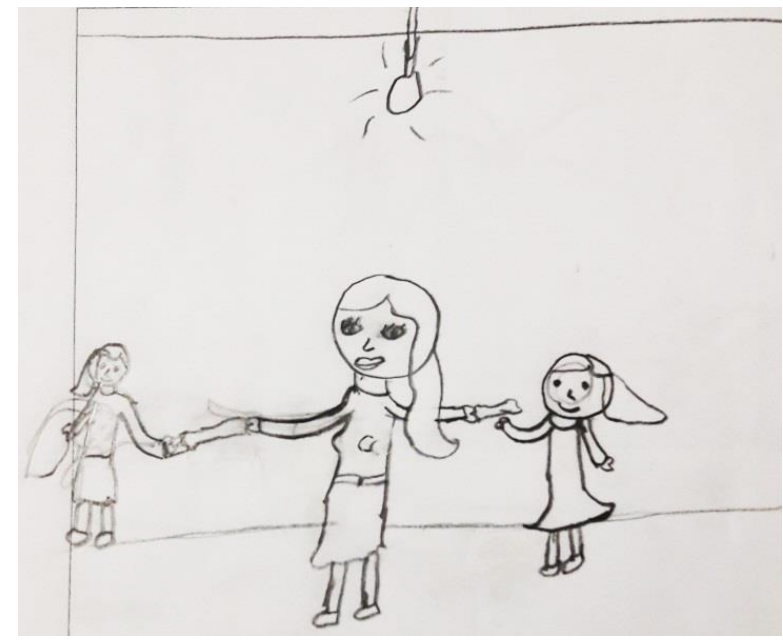

Uygulama sonras 1

\section{Resim 1. Ö3, uygulama öncesi ve sonrası çizdiği resimler}

Ö3 uygulama öncesinde çizdiği resimde "elindeki çikolatayı çocuğuna veren bir anne" resmettiğini belirtmiştir. Ö3 uygulama sonrasında çizdiği resmi açıklarken "elindeki çikolatayı çocukları arasında eşit olarak paylaştıran bir anne” çizdiğini ifade etmiştir.

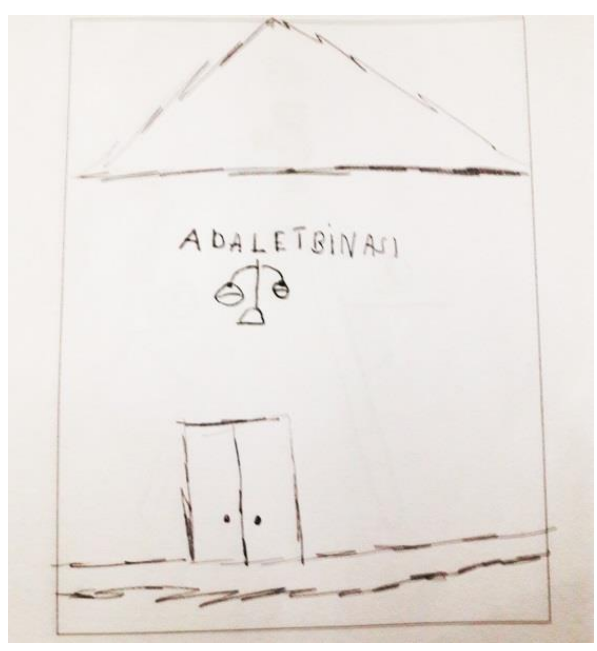

Uygulama öncesi

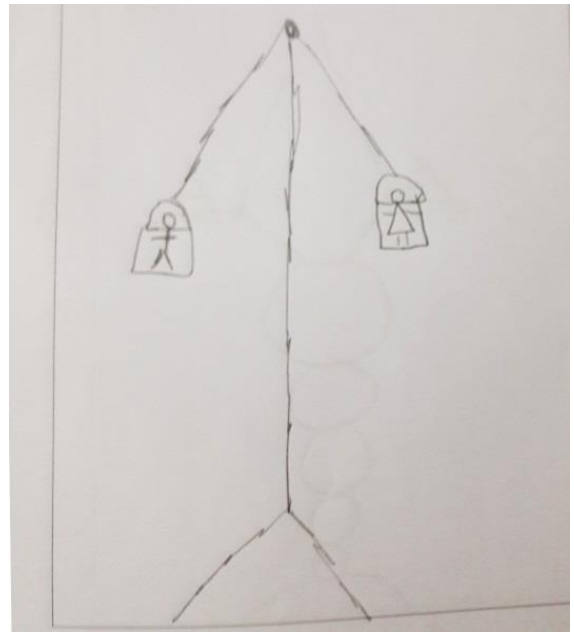

Uygulama sonras1

\section{Resim 2. Ö6, uygulama öncesi ve sonrası çizdiği resimler}

Ö6 uygulama öncesi yaptı̆̆ çizimde "adalet" kavramını adalet binası formunda ifade ederken uygulama sonrasında çizdiği resimde adaleti eşit kollu terazide kadın ve erkek şeklinde çizmiştir. Ö6 uygulama sonrasında çizdiği resmi "kadın ve erkek eşit olursa adalet olur" 
şeklinde yorumlamıştır. İlk resimde kavramla ilgili somut yapılar ön planda tutulurken son resimde kavramın ne anlam ifade ettiği soyut olarak anlatılmaya çalışılmıştır.

\section{Kelime İlişkilendirme Testinden Elde Edilen Bulgular}

Uygulama öncesi ve sonrasında öğrencilerden "adalet, eşitlik ve hak" kavramlarının akıllarına başka hangi kavramları/kelimeleri getirdiğini yazmaları istenmiştir. Uygulama öncesinde yapılan kelime ilişkilendirme çalışmasında öğrenciler; adalet kavramını 28, eşitlik kavramını 36, hak kavramını 33 farklı kavram ile ilişkilendirmiştir. Uygulama sonrasında yapılan kelime ilişkilendirme çalışmasında adalet kavramını 28, eşitlik kavramını 32, hak kavramını 33 farklı kavram ile ilişkilendirmişlerdir. Bu veriler 1şığında kavramların ilişkilendirildiği kelimelerin tekrar sıklığı 2 ve daha fazla olanlar dikkate alınarak Şekil 1 ve 2 oluşturulmuştur. Şekillerde bulunan kırmızı renkli ok işaretleri 5 tekrar, turuncu ok işaretleri 4 tekrar, mavi ok işaretleri 3 tekrar ve yeşil ok işaretleri 2 tekrarı gösterecek şekilde kodlanmıştır.

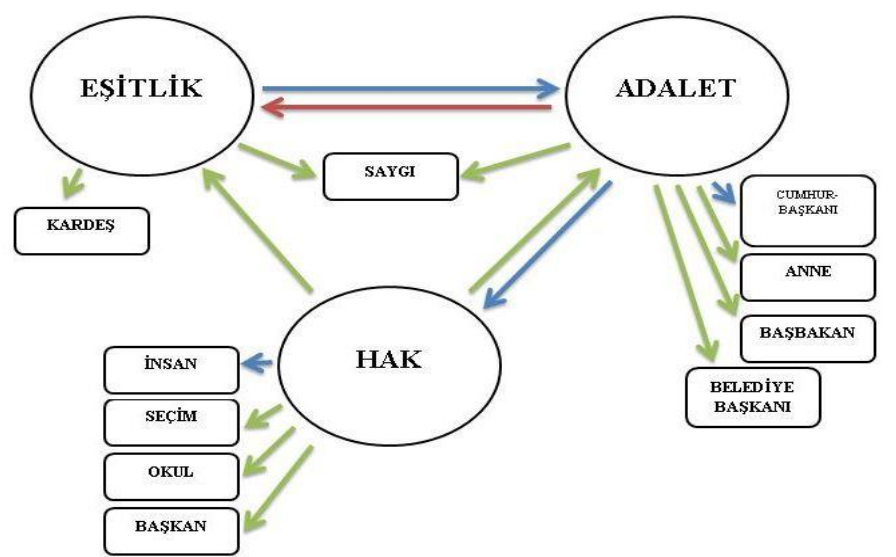

\section{Şekil 1. Uygulama öncesi yapılan KİT diyagramı}

Uygulama öncesinde adalet kavramı için en çok yazılan kelime 'eşitlik' ( $\mathrm{f}=5)$, eşitlik kavramı için 'adalet' ( $\mathrm{f}=3$ ), hak kavramı için 'insan' $(\mathrm{f}=3)$ olmuştur. Adalet ve eşitlik kavramları "saygı" kavramında buluşurken hak-eşitlik ve hak-adalet arasında ortak bir kavramın ortaya çıkmadığı görülmüştür.

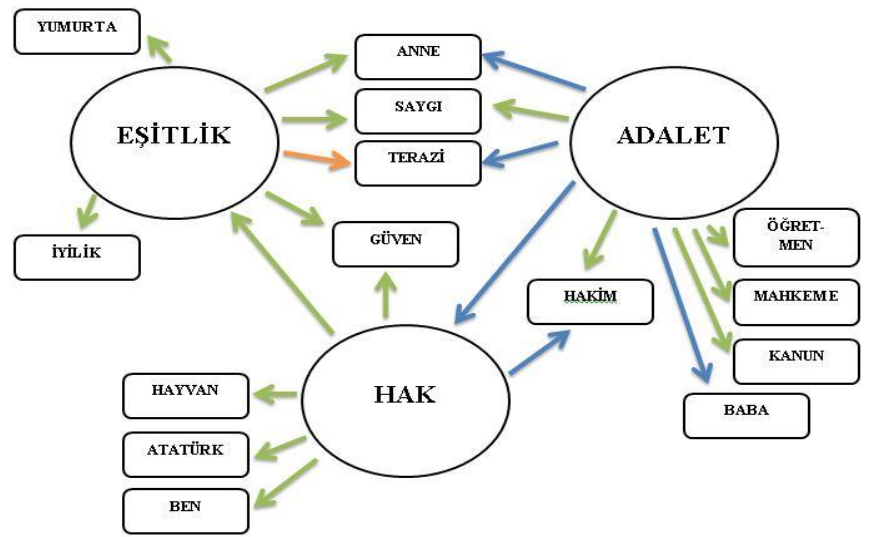

Şekil 2. Uygulama sonrası yapılan KİT diyagramı 
Uygulama sonrasında adalet kavramı için en çok yazılan kelimeler 'anne, baba, hak ve 'terazi' ( $\mathrm{f}=3$ ), eşitlik kavramı için 'terazi' ( $\mathrm{f}=4)$, hak kavramı için 'hâkim' ( $\mathrm{f}=3$ ) olmuştur. Şekil 2'ye göre üç kavram arasında daha karmaşı bir ilişki ağ kurulduğu gözlenmektedir. Eşitlik ve adalet kavramları "anne, saygı, terazi" kavramlarında buluşurken, eşitlik ve hak kavramları "güven" kavramında, adalet ve hak kavramları ise "hâkim" kavramında buluşmuştur. Kavramsal değişimi sağlayan ve ölçen stratejilerden biri olan kelime ilişkilendirme testinin (Bahar, 2003) bu araştırmada kullanılması ile uygulama sonrasında "eşitlik", "adalet" ve "hak" kavramlarının birbirinden farklı kavramlar olduğunun çocuklar tarafından fark edildiği görülmektedir.

\section{Yarı Yapılandırılmış Görüşme Formundan Elde Edilen Bulgular}

YYGF'den elde edilen bulgular aşağıda verilmiştir. Öğrencilerin verdikleri yanıtların birden çok koda tabi olabilme özelliğinden dolayı bazı frekans sayıları toplam öğrenci sayısından fazla olabilmektedir.

Soru 1. Sence "Adalet" ne demektir? Yaptı̆̆ın tanıma göre adil biri olduğunu düşünüyor musun?

Öğrencilerin soru 1'e verdikleri yanıtlar Tablo 3'te sunulmuştur.

Tablo 3. Soru 1 için Öğrencilerin Verdikleri Yanıtların Analiz Sonuçları

\begin{tabular}{llll}
\hline Uygulama Öncesi & & Uygulama Sonrası & \\
\hline Kod & Frekans & Kod & Frekans \\
\hline Eşitlik & 7 & Haksızlık yapmama & 3 \\
Doğruluk & 1 & Eşitlik & 3 \\
& & Adil davranma & 1 \\
& & Düşünceli olma & 1 \\
\hline
\end{tabular}

Öğrencilerin uygulama öncesi verdikleri yanıtlar birbirine benzer iken uygulama sonrasında yanıtlarda anlamlı bir farklılaşma ve farklı boyutları ile kavramı ele alma durumu görülmektedir. Soru 1'in devamında öğrencilere yaptıkları tanıma göre adil biri olup olmadıkları sorulmuştur. Öğrencilerin \% 87,5'i ( $\mathrm{f}=7$ ) uygulama öncesinde kendini adaletli olarak görürken, uygulama sonrasında ise \% 75' inin ( $\mathrm{f}=6$ ) kendini adaletli gördüğü, \% 12,5' $\mathrm{i}(\mathrm{f}=1)$ bazen adaletli gördüğü, \% 12,5'inin (f=1) de hiçbir zaman adaletli olmadığı yönünde görüş belirttiği tespit edilmiştir.

Soru 2. Adil olmak neden önemlidir?

Öğrencilerin soru 2'ye verdikleri yanıtlar tablo 4'te sunulmuştur. 
Tablo 4. Soru 2 için Öğrencilerin Verdikleri Yanıtların Analiz Sonuçları

\begin{tabular}{llll}
\hline Uygulama Öncesi & \multicolumn{2}{l}{ Uygulama Sonrası } & Frekans \\
\hline Kod & Frekans & Kod & 1 \\
\hline Eşitliği sağlamak için. & 1 & Arkadaş sayımın azalmaması için. & 1 \\
Kırılmamak için. & 1 & Arkadaşımızın bize küsmemesi için. & 1 \\
Kendimize zarar vermemek için. & 1 & İnsanlarla daha iyi geçinmek için. & 2 \\
Başkalarını mutlu etmek için. & 1 & Güvenilir olmak için. & 2 \\
Adaletsizlik kötü olduğu için. & 1 & Haksızlığın olmaması için. & 1 \\
Haksızlığın olmaması için. & 1 & Sevilmek için. & 2 \\
Kavganın olmaması için. & 1 & & \\
Kötü biri olmamak için. & 1 & & \\
\hline
\end{tabular}

Uygulama öncesi öğrencilerin verdikleri cevapların birbirinden farklı oldukları, adil olmanın önemine ilişkin ortak bir yargının olmadığı görülmektedir. Uygulama sonrasında öğrencilerin görüşlerinde insanlarla daha iyi ilişkiler kurmak ve güvenilir olmak için gibi ortak bir anlayışın oluşmaya başladığı görülmektedir.

Soru 3. Adil biri olmak için nasıl davranmak gerekir?

Öğrencilerin soru 3'e verdikleri yanttlar Tablo 5'te sunulmuştur.

Tablo 5. Soru 3 için Öğrencilerin Verdikleri Yanıtların Analiz Sonuçları

\begin{tabular}{llll}
\hline Uygulama Öncesi & & Uygulama Sonrası & \\
\hline Kod & Frekans & Kod & Frekans \\
\hline Eşit olmak & 3 & Adaletli olmak & 3 \\
Adaletli olmak & 3 & İyi davranmak & 3 \\
Dürüst olmak & 2 & Dürüst olmak & 1 \\
Taraf tutmamak & 1 & Haksszlık yapmamak & 1 \\
Paylaşımcı olmak & 2 & Eşit olmak & 1 \\
Merhametli olmak & 2 & $\begin{array}{l}\text { Bir şey alırken herkese yetecek kadar } \\
\text { almak }\end{array}$ & 1 \\
\hline
\end{tabular}


Tablo 5'e göre öğrencilerin verdikleri yanıtlarda belirgin bir farklılık olmadığı görülmektedir.

Soru 4. Şimdiye kadar birine adaletsizlik yaptığını düşünüyor musun?

Öğrencilerin soru 4'e verdikleri yanttlar Tablo 6'da sunulmuştur.

Tablo 6. Soru 4 için Öğrencilerin Verdikleri Yanıtların Analiz Sonuçları

\begin{tabular}{lllc}
\hline Uygulama Öncesi & \multicolumn{3}{c}{ Uygulama Sonrası } \\
\hline Kod & Frekans & Kod & Frekans \\
Evet & 3 & Evet & 4 \\
Hayır & 5 & Hayır & 4 \\
\hline
\end{tabular}

Soru 4'e evet cevabını veren öğrencilerden yaptıkları adaletsizlikleri açılamaları istenmiştir. Ön testlerde öğrenciler aile içinde adaletsiz davrandıklarını belirtirken bu adaletsizliğin ne olduğu ile ilgili bilgi vermemişlerdir. Son testlerde ise adaletsiz davrandığını belirten Ö4 "Kardeşim ve annemle dışarı çıkmıştık. Bana oyuncak aldık. Ama kardeşime almadık.", Ö3 ise "Babamın verdiği 3 TL harçlığın 2 TL'sini ben aldım, kardeşime ise 1 TL verdim.” şeklinde açıklama yapmışlardır.

Soru 5. Sence adalet ve eşitlik arasında bir fark var mı?

Öğrencilerin Soru 5'e verdikleri yanttlar Tablo 7'de sunulmuştur.

Tablo 7. Soru 5 için Öğrencilerin Verdikleri Yanıtların Analiz Sonuçları

\begin{tabular}{lllc}
\hline Uygulama Öncesi & \multicolumn{3}{c}{ Uygulama Sonrası } \\
\hline Kod & Frekans & Kod & Frekans \\
\hline Evet & 1 & Evet & 8 \\
Hayır & 6 & Hayır & 0 \\
Bilmiyorum & 1 & Bilmiyorum & 0 \\
\hline
\end{tabular}

Uygulama öncesinde öğrencilerin çoğunluğu adalet ve eşitlik arasında bir fark olmadığını belirtirken uygulama sonrasında bir farklılığın olduğunu belirtmişlerdir. Soru 5'e evet cevabı veren öğrencilerden bu farkın ne olduğunu açıklamaları istenmiştir. Ön testlerde tek evet cevabını veren Ö3 "bazen eşit olan şeylerin ikisi de kötü olabiliyor" açıklamasını yapmıştır. Son testlerde katılımcıların tamamı adalet ve eşitlik arasında bir fark olduğunu belirtmiştir. Ö1 yanıtında adaleti sağlamak için "hak" kavramının önemini vurgularken, Ö2 adaletli olmanın eşitliği getirmediğini ifade etmiştir. Ö4, Ö5 ve Ö8 adalet ve eşitlik arasındaki fark1 somut bir örnek üzerinden anlatmaya çalışmışlardır.

Soru 6: Sence yaşadiğımız yer/ülke adil bir yer mi? Neden?

Öğrencilerin Soru 6'ya verdikleri yanıtlar Tablo 8'de sunulmuştur. 
Tablo 8. Soru 6 için Öğrencilerin Verdikleri Yanıtların Analiz Sonuçları

\begin{tabular}{llll}
\hline Uygulama Öncesi & \multicolumn{3}{c}{ Uygulama Sonrasi } \\
\hline Kod & Frekans & Kod & Frekans \\
\hline Evet & 4 & Evet & 0 \\
Hayır & 3 & Hayır & 8 \\
Biraz & 1 & & \\
\hline
\end{tabular}

Uygulama öncesinde yaşadığımız yer/ülkenin adil olmadığını belirten öğrenciler neden olarak savaşları ve trafik sorunlarını gerekçe göstermişlerdir. Uygulama sonrasında ise öğrenciler birçok değişkeni dikkate alarak açıklama yapmışlardır. Uygulama sonrasında Ö1 “ tavuklar bize yumurta yapıyor ama biz tavukların istediğini vermiyor olabiliriz", Ö5 "çünkü hayvanlara kötü davranıyoruz, onları kafeslere tıkıyoruz." ve Ö6 "çünkü eşitlik herkese yetmiyor." ifadelerini kullanmışlardır. Uygulama sonrasında yalnızca insanların değil hayvanların da adalete ihtiyaçları olduğunu belirten öğrenciler eşitliğin adaleti sağlamadığı yönünde de açıklamalar yapmışlardır. Çalışmada yer alan yaratıcı drama oturumlarından "Herkes İçin Adalet" oturumu hayvan haklarına vurgu yapan bir oturumdur. Bu oturumun etkisinin bazı öğrencilerin bu soruya verdikleri cevaplara yansıdığı görülmektedir.

\section{Tartışma ve Sonuç}

Uygulama öncesi adalet kavramını eşitlik olarak açıklayan öğrenciler uygulama sonrasında haksızlık yapmama, adil davranma ve düşünceli olma ile de ilişkilendirmişlerdir. Uygulama öğrencilerin kavramı farklı boyutlarıyla da ele almalarını sağlamıştır.

Uygulama öncesinde öğrencilerin yaptıkları çizimlerde adalet kavramını açıklarken yazı kullanmaya ihtiyaç duydukları gözlenmiştir. Ancak uygulama sonrasında kavramı açıklarken günlük hayattan bir kesit çizmeye çalışmışlardır. Bu da kavramın somutlaştırıldığının bir göstergesidir.

Adalet, eşitlik ve hak kavramları ile ilgili yapılan KİT sonucunda uygulama öncesinde bu üç kavram arasında ortak bir ilişki kurulamamış, eşitlik ve adalet kavramları saygı kavramında buluşturulmuştur. Uygulama sonrasında ise eşitlik ve adalet kavramları "anne, sayg1 ve terazi" kavramlarında buluşturulmuş, eşitlik ve hak kavramları "güven" kavramında, adalet ve hak kavramları ise "hâkim" kavramında buluşmuşlardır. Uygulama sonunda öğrencilerin kavram dünyasında bir çeşitliliğin ortaya çıktığı görülmüştür.

Uygulama öncesinde öğrencilerin büyük bir çoğunluğu adalet ve eşitliği aynı olarak kabul ederken uygulama sonrasında kavramların farklı olduklarını belirtmişler ve bu farklılığı günlük yaşam kesitlerinden örnekler vererek açıklamaya çalışmışlardır. Bu sonuç Aykaç’ın (2014) “değerlerin duyuşsal yönü göz önüne alındığında, yaparak yaşayarak öğrenmeye olanak sağlaması ve yaşantıları davranışa dönüştürmede etkili olması bakımından yaratıcı dramanın değer öğretiminde etkili bir yöntem olduğu" görüşünü de desteklemektedir. Yine alan yazına bakıldığında yaratıcı drama yöntemi ile kavram yanılgılarının giderilmesi üzerine yapılmış 
araştırmaların olduğu görülmektedir (Başkan, 2006; Gültepe, Tekkaya, Çapa ve Yılmaz, 2000; Yıldırım ve Sinan, 2008;). Bu araştırmada da benzer sonuçlar elde edilmiştir.

Kavram yanılgılarının ortadan kaldırılması aşamasından sonra öğrencilerin mevcut değerleri kavramaları ve günlük hayatta karşılaşabilecekleri durumları görebilmeleri bakımından yaratıcı drama yöntemi içerisinde sık sık kullanılan örnek olay inceleme tekniği etkilidir. Örnek olay inceleme tekniği öğrencilere ders kazanımlarına uygun bir olayın sunulması ve öğrencilerin bu konu hakkında tartışıp yorum yapmalarını sağlayan, öğrencilerde problem çözme, tartışma, empati, kritik düşünme ve yaratıcılığı geliştiren bir yöntemdir (Tan, 2005). Bu teknik sayesinde kavram hakkında derinlemesine bilgi sahibi olmak ve kavramı günlük hayatla ilişkilendirmek mümkün olmaktadır. Yine yaratıcı drama yöntemi ile yapılandırılmış ders planlarında doğaçlama ve rol oynama teknikleri sık sık kullanılmaktadır. $\mathrm{Bu}$ sayede öğrencilerin değerleri içselleştirmesi sağlanabilmektedir. Çünkü doğaçlama sırasında katılımcılar, yaşadıkları ya da gözlemledikleri gerçek olaylarla kurgusal olan arasında bağ kurarak, değişik duyular yoluyla dişavurumda bulunabilirler (Adıgüzel, 2015).

Üstün yetenekli öğrencilere verilen yaratıcı drama ile yapılandırılmış beş haftalık adalet eğitiminden sonra adalet değerine ilişkin kavram yanılgıları büyük ölçüde ortadan kaldırılmıştır. Soyut bir kavram olan adalet kavramına ilişkin öğrenciler günlük yaşamla ilişkilendirebildikleri tanımlar yapabilir, örnek verebilir hale gelmişlerdir. Ayrıca adaletin yalnızca insanlar için değil diğer canlılar için de gerekli olduğu yönünde çıkarımlarda bulunmuşlardır. Bolay’a (2007) göre öğrencilerin değerleri benimseyip önem vermeleri için değerleri içselleştirmeleri gerekmektedir. Öğretmenlerin, ders işleme sürecinde kullandığı yöntem ve teknikler, istenilen değerlerin, öğrenciler tarafindan benimsenmesini ve içselleştirmesini kolaylaştırabilir. Değer eğitimi gerçekleştirilen derslerde kullanılabilecek yöntem ve tekniklerden bir tanesi de dramadır (Halstead,1996'dan akt. Yazıc1, 2006). Üstün yetenekli öğrenciler ile gerçekleştirilen bu araştırma üstün yetenekli öğrencilere verilecek değerler eğitiminin yaratıcı drama yöntemi ile yapılandırılmasının etkili olacağı yönünde bulgular ortaya koymuştur.

Eğitimleri boyunca; öğrencilere, sadece bilişsel ve devinişsel kazanımların verildiği bir anlayış, toplumu oluşturan bireylerin, değer ve tutum gibi duyuşsal kazanımları elde edememelerine neden olmaktadır (Yazıcı, 2006). Bu durum üstün yetenekli öğrenciler için de geçerlidir. Üstün yetenekli öğrencilerin var olan potansiyellerine ulaşmalarını sağlamak amaciyla birçok müfredat geliştirme modeli ortaya konulmuştur. Bu modellerin ortak özelliği üstün yetenekli öğrencilerin bilişsel ve devinişsel anlamda gelişimlerini hedefliyor olmalarıdır. Hâlihazırda ülkemizde üstün yetenekli öğrencilere verilen eğitimler de bu yöndedir. Bilim ve sanat merkezlerinde yaygın olarak kodlama, robotik, akıl ve zekâ oyunları, yaratıcı yazarlık, bilimsel araştırma yöntemleri, STEM gibi eğitimlerin ön planda tutulduğu görülmektedir. Bilim ve Sanat Merkezleri destek eğitimi programında doğrudan değerler eğitimi kapsamında hazırlanmış etkinliklere rastlanmaktadır, ancak bir bütünlük ve standardın olmadığ görülmektedir. Gerek Türkiye'de gerekse diğer ülkelerde üstün yetenekli öğrencilerin duyuşsal anlamda gelişimlerini sağlayacak tam ve etkili bir model ortaya konulmamıştır. Yine aynı şekilde değerler eğitimi uygulamalarında da üstün yetenekli öğrenciler için geliştirilmiş bir değerler eğitimi programı bulunmamaktadır. Doğanay (2006), değer eğitiminin eğitimin genel amaçları arasında her zaman yer almış olmasına rağmen nasıl öğretileceği belirtilmediği için hep eksik kaldığını, planlı olmak yerine örtük bir şekilde formal eğitim içinde yer aldığını 
belirtmektedir. Bu durum gerek değer öğretimi gerekse değer eğitimi açısından eksikliklerin oluşmasına neden olmaktadır. Bu bakımdan üstün yetenekli öğrencilerin değerler eğitimi ihtiyacının karşılanması için bir model ortaya konulması gerekmektedir.

Öncelikle değer ifadelerinin soyut kavramlar olması nedeniyle özellikle ilkokul düzeyindeki üstün yetenekli öğrencilerin kavramsal yanılgılarının yüksek olduğu sonucuna ulaşılmıştır. Oluşturulacak bir değerler eğitimi programında öncelikli hedef olarak öğrencilerde bulunan kavram yanılgılarının ortadan kaldırılması gerekmektedir. Kavram yanılgılarının ortadan kaldırılması noktasında yaratıcı drama yöntemi önemli avantajlara sahiptir. Çünkü yaratıcı drama içerisinde aktif öğrenme, sosyal öğrenme, kavram öğrenme, keşfederek öğrenme gibi birçok öğrenme türlerini bir arada sunmaktadır (Karadağ ve Çalışkan, 2008). Taşpınar da (2009) yaptığı araştırmanın bulgularına dayanarak, özellikle küçük yaşlarda değerlerin kazandırılmasında yaratıcı drama yönteminden yararlanılması gerektiği önerisinde bulunmuştur.

Sonuç olarak üstün yetenekli öğrenciler için değer öğretimi ve değer eğitimi bakımından bir programa gereksinim duyulmaktadır. Oluşturulacak bir programın yapılandırılmasında yaratıcı drama yöntemi hem değer öğretimi hem de değer eğitimi aşamalarında kullanılmalıdır. Çünkü yaratıcı drama yöntemi yaparak yaşayarak öğrenmeye fırsat vermesi bakımından yapılandırmacılık anlayışına en uygun öğretim yöntemlerinden bir tanesidir. Yaratıcı drama yönteminin öğrenci katılımı bakımından bakıldığında diğer öğretim yöntemlerine göre üstün yönlerinin olduğu görülmektedir. Adıüzzel'in (2006) deyimiyle yaratıcı drama kavramı; "çocuğun ve ergenin öğrenme yaşantısında onların duyuşsal yaşantılarını, düşlem gücünü, imgesel düşünmeyi aktif hale getirmede ve öğrenme süreçlerine etkince katılmasında etkili bir yöntemdir."

Yaratıcı drama yöntemi gerek akademik başarı gerekse tutum, ilgi ve motivasyon bakımından öğrenci gelişimini destekleyen bir yapıdadır. Yaratıcı dramanın akademik başarıyı artırdığı (Atalay ve Şahin, 2012; Üstündağ, 2008), öğrencilerin tutumlarını geliştirdiği (Bailey ve Watson, 1998; Günaydın, 2008; Kırmızı, 2009; Namdar ve diğ., 2018; Sağırlı ve Gürdal, 2002; Yılmaz-Cihan, 2006;), motivasyonlarını artırdığı (Alrutz, 2004; Başkan, 2006) çeşitli araştırmalar ile ortaya konulmuştur. Yaratıcı drama yöntemi ile bütünleşik birçok öğretim yöntemi / tekniği bulunmaktadır. Bu öğretim yöntem ve teknikleri farklı öğrenme stilleri olan öğrenciler için avantaj sağlamaktadır. Bu nedenlerle yaratıcı drama yönteminin üstün yetenekli öğrencilerin değer öğretimi ve değer eğitimi etkinliklerinde de kullanılması önerilmektedir.

\section{Kaynakça}

Adıgüzel, Ö. (2006). Yaratıcı drama kavramı, bileşenleri ve aşamaları. Yaratıcı Drama Dergisi, 1(1), 1731.

Adıgüzel, Ö. (2015). Eğitimde yaratıcı drama (6. Baskı). Ankara: Pegem A Yayınevi.

Alrutz, M. (2004). Granting science a dramatic license: Exploring a 4th grade science classroom and the possibilities for integrating drama. Teaching Artist Journal, 2(1), 31-39.

Altunışık, R., Coşkun, R., Yıldırım, E. ve Bayraktaroğlu, S. (2001). Sosyal bilimlerde araştırma yöntemleri. Adapazarı: Sakarya Kitabevi.

Atalay, O., ve Şahin, S.(2012) İlköğretim 5. sınıf bilişim teknolojileri dersinin öğretiminde drama öğretim yönteminin öğrenci başarısına etkisi. Eğitim Teknolojisi Kuram ve Uygulama, 2(2), 1-9. 
Aykaç, M. (2014). The values adopted by individuals receiving different levels of creative drama education. International Journal of Academic Research, 6(1), 240-252.

Bahar, M., Johnstone, A. H., \& Sutcliffe, R. G. (1999). Investigation of students' cognitive structure in elementary genetics through word association tests. Journal of Biological Education, 33(3), 134141.

Bahar, M. ve Özatlı, N. S. (2003). Kelime İlişkilendirme Yöntemi ile lise 1. Sınıf öğrencilerinin canlıların temel bileşenleri konusundaki bilişsel yapılarının araştırılması. Balıkesir Üniversitesi. Fen Bilimleri Dergisi, 5(1).

Bahar, M. (2003). Misconceptions in biology education and conceptual change strategies, Educational Sciences: Theory \& Practice, 3(1) 55-64.

Bailey, S., \& Watson, R. (1998). Establishing basic ecological understanding in younger pupils: a pilot evaluation of a strategy based on drama/role play. International Journal of Science Education, 20(2), 139-152.

Başkan, H. (2006). Fen ve teknoloji öğretiminde drama yönteminin kavram yanllgllarının giderilmesi ve öğrenci motivasyonu üzerine etkisi. Yayımlanmamış Yüksek Lisans Tezi. Karadeniz Teknik Üniversitesi Fen Bilimleri Enstitüsü, Trabzon

Bencik Kangal, S. ve Arı, M. (2013). Üstün yetenekli ve normal gelişim gösteren çocukların ahlaki yargı düzeyine yaratıcı drama programlarının etkisinin incelenmesi, Eğitim ve Bilim, 38(170), 308320.

Bolay, S. H. (2007). Değerlerimiz ve günlük hayat. Değerler Eğitimi Merkezi Dergisi, 1(1), 12-19. http://www.dem.org.tr/dem_dergi/1/dem1 mak3.pdf sayfasından erişilmiştir.

Cardellini, L. \& Bahar, M. (2000). Monitoring the learning of chemistry through word association tests. Australian Chemistry Resource Book,19, 59-69.

Clark, B. (1997). Growing up gifted (5. Ed.). Upper Saddle River, New Jersey, Columbus, Ohio: Merrill

Çepni, S., \& Gökdere, M. (2002). Profiles of the gifted students in Turkey. In Education: Changing Times, Changing needs" Fisrst international conference on education. Faculty of education Eadstern mediterranean University Gazimağusa, Turkish republic of Northern Cybrus May (pp. $8-10)$.

Çepni, S. (2007). Araştırma ve proje çallş̧malarına giriş. (Genişletilmiş 3. Baskı), Trabzon: Celepler Matbaacilik.

Çetinkaya, Ç. ve Döner, İ. (2013). Türkiye'de üstün yeteneklilere tanınan hakların incelenmesi. Sakarya University Journal of Education, 2(3), 7-20.

Davaslıgil, Ü. (2004). Yüksek matematik yeteneğinin erken kestirimi, I. Türkiye Üstün Yetenekli Çocuklar Kongresi, M.Ü. \& Çocuk Vakfı Yayınları, İstanbul, ss. 265-283.

Doğanay, A. (2006). Değerler eğitimi. C. Öztürk (ed), Hayat bilgisi ve sosyal bilgiler öğretimi. Ankara: Pegem A Yayıncilik.

Dorhout, A. (1983) Student and teacher perception of preferred teacher behaviors among the acedemically gifted. Gifted Child Quarterly 27(3), 122-125

Ercan, F. ve Taşdere, A. (2010). Kelime ilişkilendirme testi aracılı̆̆ıyla bilişsel yapının ve kavramsal değişimin gözlenmesi. Türk Fen Eğitimi Dergisi (TÜFED), 7(2), 136-154.

Erden M. ve Akman Y. (1995). Eğitim psikolojisi. Ankara: Arkadaş Yayınevi.

Feldhusen, J. F. (1997). Educating teachers for work with talented youth. Handbook of gifted education, 2, pp. 547-552

Feldhusen, J. F., \& Jarwan, F. A. (2000). Identification of gifted and talented youth for education programs. In K. A. Heller, F. J. Mönks, R. J. Sternberg \& R. F. Subotnik (ed.), International handbook of giftedness and talent, (2nd ed. ss. 271-282). Oxford, UK: Elsevier Science Ltd.

Fiedler, E.D., Lange, R., \& Wibebrenner, S. (2002). Guest editors' comments on in search of reality: Unraveling the myths about tracking, ability grouping, and the gifted, Roeper Review, 24(3), 108-108. 
Gangi, J.M. (1990). Higher level thinking skills through drama. Gifted Child Today, 13(1), 16-19.

George, D. (2003). Gifted education. London, Britain: David Fulton Publishers.

Gökdere, M. ve Çepni, S. (2003). Üstün yetenekli çocuklara verilen değerler eğitiminde öğretmenin rolü. Değerler Eğitimi Dergisi, 1 (2), 93-107.

Gökdere, M. ve Çepni, S. (2005). Üstün yeteneklilerin fen bilimleri öğretmenlerine yönelik bir hizmet içi eğitim uygulama ve değerlendirme çalışması. Gazi Üniversitesi Türk Eğitim Bilimleri Dergisi, 3(3), 271-296.

Gönen, M. ve Dalkılıç, N. (2003), Çocuk eğitiminde drama, yöntem ve uygulamalar, İstanbul: Epsilon Yayıncilik.

Gültepe, M. B., Yıldırım, O. ve Sinan, O. (2008). Solunum sistemi konusunun oluşturmacı yaklaşıma dayalı ögretiminin 6. sınıf öğrenci başarısına etkisi. Illköğretim Online, 7(2), 522- 536

Günaydın, G. (2008). Ilköğretim 6. sinıf sosyal bilgiler öğretiminde drama yönteminin erişi ve tutum üzerindeki etkisi (Doktora tezi).Dokuz Eylül Üniversitesi Eğitim Bilimleri Enstitüsü, İzmir.

Ihlamur, Ş. ve Aykaç, M. (2016). Sanat eğitiminde Vincent Van Gogh'un eserleriyle kurgulanan yaratıcl drama etkinliklerinin üstün zekal ve yetenekli öğrencilerin yaratıcllıklarına etkisi. 4. Uluslararası Eğitim Programları ve Eğitim Kongresi.

Halmatov, S. (2015). Çocuk resmileri analizi ve psikolojik resim testleri. Ankara: Pegem Yayıncılık.

Halpen, W.G., Payne A., \& Ellet C. D. (1974). In search of the creative personality among gifted groups. Gifted Child Quarterly, 18(1), 31-33.

Hansel, N. H.(1991). Social leadership skills in young children. Roeper Review, 14 (1), 4- 6.

Hansen. J. B., \& Feldhusen J.F. (1994) Comparison of trained and untrained teachers of gifted student (1994) Gifted Child Querterly 38(3), 115-121.

Karadağ, E. ve Çalışkan, N. (2008). Kuramdan uygulamaya ilköğretimde drama, "oyun ve işleniş örnekleriyle”. Ankara: Anı Yayıncılık.

Kırmızı, F. S. (2009). Türkçe dersinde yaratıcı drama yöntemine dayalı yaratıcı yazma çalışmalarının yazmaya yönelik tutuma etkisi. Yaratıcı Drama Dergisi, 4(7), 51-68.

Lewis, G.L. (1972). Creative dramatics: Problems and processes. Communication Studies, 23 (1), 18 - 27.

Milli Eğitim Bakanlığı (2018). Bilim ve Sanat Merkezleri Yönergesi. Erişim: 28 Ağustos 2018, https://orgm.meb.gov.tr/meb iys dosyalar/2016 10/07031350 bilsem yonergesi.pdf

Maker, J. (2003). New directions in enrichment and acceleration. In N. Colangelo \& G. Davis (ed.), Handbook of gifted education, (ss. 163 - 173). Boston: Allyn and Bacon.

McNaughton, M. J. (2004). Educational drama in the teaching of education for sustainability. Enviromental Education Research, 10(2), 139-155.

Nakiboğlu, C. (2008). Using word associations for assessing nonmajor science students' knowledge structure before and after general chemistry instruction: the case of atomic structure. Chem. Educ. Res. Pract, 9, 309-322.

Namdar, A. O., Bülbül, A. N., \& Çankal, A. O. (2018) Yaratıcı drama ile canlılar dünyasına yolculuk. Kurş̧ehir Ĕ̈itim Fakültesi Dergisi.

Okyay, L. (2008). 6 yaş grubu çocukların aile resimlerinin sosyokültürel değişkenler ve davranış problemleri açısından karşılaş̧tırlması. Yüksek Lisans Tezi, Trakya Üniversitesi, Sosyal Bilimler Enstitüsü, Edirne.

Özbay, Y. ve Palanc1, M. (2011). Üstün yetenekli çocuk ve ergenlerin psikososyal özellikleri. Sakarya Üniversitesi Ĕ̈itim Fakültesi Dergisi, (22).

Renzulli, J. S. (1999). Reflections, perceptions, and future directions. Journal for the Education of the

Gifted. 23(1), 125-146.

Renzulli, J. S. (2000). The identification and development of giftedness as a pradigm for school reform. Journal of Science Education and Techology, 9(2), 95-114.

Renzulli, J.S., \& Reis, S. M., (1985). The shoolwide enrichment model: A comprehensive plan for educational excellence. Mansfield Center, CT: Creative Learning Pres. 
Renzulli, J.S., Smith, L.H., White, A.J., Callahan, C.M., Hartman, R.K. \& Westberg, K.L. (2002). Scales for rating the behavioral characteristics of superior students (Rev. ed.). Mansfield Center, CT: Creative Learning Press.

Sağırlı, H. E., \& Gürdal, A. (2002). Fen bilgisi dersinde drama tekniğinin öğrenci tutumuna etkisi. V. Ulusal Fen Bilimleri ve Matematik Eğitimi Kongresi. Erişim tarihi: 05/02/2019 Erişim adresi: http://infobank.fedu.odtu.edu.tr/ufbmek-/b_kitabi/PDF/Fen/Bildiri/t86.pdf

San, İ. (1990). Eğitimde yaratıı drama. Ankara Üniversitesi Ĕ̆itim Bilimleri Fakültesi Dergisi, 23(2), 573-583.

Sousa, D. (2003). How the gifted brain learrns. Thousand Oaks, CA: Corwin Press: A Sage Publications Company.

Steiner, H. H., \& Carr, M. (2003). Cognitive development in gifted children: Toward a more precise understanding of emerging differences in intelligence. Educational Psychology Review, 15(3), 215-246.

Stewig, J.W., \& Vail N.J. (1985). The relation between creative drama and oral language growth. The Clearing House, jstor.org

Tan, Ş. (2005), Öğretimi planlama ve değerlendirme, Ankara: Pegem A Yay.

Taşpınar, M. (2009). Eğitimde örtük program ve değerler eğitimi. I. Ulusal İyilik Sempozyumu, 25- 30.

Tekkaya, C., Çapa, Y. \& Yılmaz, Ö. (2000). Biyoloji öğretmen adaylarının genel biyoloji konularındaki kavram yanılgıları. Hacettepe Üniversitesi Eğitim Fakültesi Dergisi, 18, 140-147.

Üstündağ, T. (1994). Günümüz eğitiminde dramanın yeri. Yaşadıkça Eğitim Dergisi, 37,7-10.

Üstündağ, T. (2014). Yaratıcı drama öğretmenimin günlüğ̈̈. 12.Baskı. Ankara: Pegem Akademi.

Winstead, A. (1997). Dramatic prelude: using drama to introduce classic literature to young readers. Gifted Child Today Magazine, 20(1), 16-17,28-29,49.

Wood. B., \& Feldhusen.J.F. (1996). Creating special interest programs for gifted youth: Purdue's super saturday serves as successful model. Gifted Child Today Magasine, V19, p22.

Wu, C.F. (2008). Research for drama activities applied in creativity of elementary gifted students. Master's Thesis, Chine.

Yazıcı, K. (2006). Değerler eğitimine genel bir bakış. Türklük Bilimi Araştırmaları, 19(19), 499.

Yılmaz-Cihan, G. (2006). Fen bilgisi ögrretiminde drama yönteminin kullanımı. (Yayımlanmamış Yüksek Lisans Tezi). Pamukkale Üniversitesi, Denizli. 


\section{Extended Abstract}

\section{Introduction}

There are many different opinions about the definition of gifted children in the literature. There seems to be no consensus on a specific definition; however, gifted children can be considered as individuals performing better in cognitive, affective, and psychomotor terms compared to peers. There are studies addressing education of gifted children for a long time in Turkey as well as all over the world. Systematic and continuous implementation of these studies started in 1993 with the establishment of (the) Science and Art Centres. Gifted children are recognized by their parents and teachers due to their advanced cognitive and psychomotor skills. However, studies show that gifted children are more developed also in affective aspect than their peers. Bearing this in mind, programs and contents developed for education of gifted children should aim to support their development not only in cognitive and psychomotor but also affective domains. This reveals the need to give values education to the gifted. Despite lots of cognitive and psychomotor programs available for gifted individuals, there is no particular program on value education that can fully meet their needs in affective aspect. Values are comprised of abstract concepts. Due to this, particularly children in primary school level cannot fully understand these concepts and confuse them with different concepts. Therefore, it seems important to structure a values education program for gifted children by using creative drama method for both eliminating misconceptions and embodying the concepts of value. In this study, the value of 'justice' is taught as a concept difficult to be comprehended by elementary school children.

\section{Methodology}

The study was carried out with action research among qualitative research patterns. The study consists of three basic stages. In the first stage, the status of problem was determined and review of literature was performed. In the second stage, an action plan was developed in an attempt to solve the problem with the help of the literature review. Finally, the action plan was implemented and the results were analyzed and interpreted. The researchers and practitioner worked together in all three stages. The study was carried out with 4 girls and 4 boys in the 3rd grade level in a science and art centre operating in the Eastern Black Sea Region. Before the implementation, 5 sessions were prepared on justice education by using creative drama, each session consisting of 2 course hours. The implementation was completed in 5 weeks, with one session each week. Data collection tools were applied to children as pre and post-test. For this study, 3 different qualitative measurement tools were used. The tools were developed by the researchers. 'Drawing and interviewing' technique and 'word association test' were used to reveal the way that children perceive the concept. Then, 'semi-structured interview form' was used to reveal in depth the change caused by the implementation on the participants. The data were analyzed with descriptive analysis and content analysis among qualitative data analysis techniques.

\section{Findings}

When the drawings by the children about the concept of 'justice' before and after the application were examined, it was observed that they needed to write in the drawings in order to explain the concept before the application. However, in the post-test, they were found to explain the concept of 'justice' through everyday events in their drawings. In the word association test 
related to the concepts of 'justice, rights, equality' before the application, the concept of justice was found to be mostly associated with equality. While the concepts of justice and equality were seen to both lead to the idea of "respect", a common concept did not emerge between rightsequality or rights-justice. The word association test applied as post-test revealed a more complex network of relationships among the three concepts. For example, the concepts of equality and justice were combined under "mother, "respect", and "balance"; the concepts of equality and rights were under "trust"; and the concepts of justice and rights were appointed under the concept of "judge." It was found out that although the concepts of justice and equality were confused and they could answer the questions with difficulty and produced superficial responses prior to the implementation. On the other hand, during post-test, they could explain the difference between justice and equality through concrete examples and argue that justice is necessary not only for human beings but also for other living things.

\section{Discussion}

It was seen that in reference to education of gifted children, the first things that comes to mind are coding, robotics, mind and intelligence games, creative writing, scientific research methods, and applications like STEM and so on. As a matter of fact, gifted children need values education at least as much as the foregoing. Talented individuals who are in a leading position in science, art and politics need to know and embody the national and spiritual values and also universal values. In a values education program to be developed for gifted individuals; it is thought that creative drama will provide important advantages to developers and practitioners as a powerful method. In relation with both value teaching and values education, creative drama comprises many components which gifted children would enjoy. 


\section{EKLER}

\section{I. Örnek Ders Planı}

\section{Oturum}

\section{Kazanım:}

- Müziğin ritmine uygun dans eder.

- Adaletin ne olduğunu açıklar.

- Bir anlaşmazlık karşısında adaleti sağlamak için çözüm önerisi sunar.

- Mahkemelerin adaleti sağlamak için kurulduğunu fark eder.

\section{Yöntem/Teknikler:}

Dans, Doğaçlama, Örnek Olay İncelemesi, Liderin Role Girmesi.

\section{Hazırlık Çalışmaları:}

1.Etkinlik: Öğrenciler çemberde toplanır. Öğrencilerden eşit kollu bir terazi olmaları istenir. Müziğin ritmine göre herkesin sınıf içinde dolaşması ve terazinin kollarını bir aşağı bir yukarı hareket ettirmesi istenir. Müziğin bitişi ile yeniden çemberde toplanılır.

2.Etkinlik: Çemberin ortasındaki alana her biri 4 parçaya ayrılmış adalet çekici, terazi, sanık sandalyesi, avukat cüppesi gibi resimler karışık olarak dağıtılır. Müzik başladığında öğrencilerden karışık olarak verilen bu resimleri doğru şekilde birleştirerek panoya asmaları istenir.

\section{Canlandırma:}

3.Etkinlik: Eğitim ortamı bir mahkeme salonunu andıracak şekilde düzenlenir. Davalı ve avukatı, davacı ve avukatı, hâkim ve jüri üyeleri için uygun yerlere sandalyeler yerleştirilir. Her bir rol ismi küçük kâğıtlara yazılarak kapalı olarak öğrencilere çektirilir. Roller "davalı, davalı avukatı, davacı, davacı avukat1, jüri 1 , jüri 2 , jüri 3 , jüri $4, \ldots$ ”. Herkes rolüne uygun olan sandalyeye oturur.

Lider kahramanlar hakkında bilgi verir.

\section{Ahmet Bey:}

Evli ve 1 çocuk babasıdır. On yaşındaki oğlu teknolojik aletleri çok sevmektedir. Sürekli babasından yeni bir bilgisayar, cep telefonu, tablet gibi pahalı eşyalar istemektedir. Babası oğlunun bir dediğini iki etmeden yerine getirmektedir.

\section{Serkan Bey:}

Evli ve 3 çocuk babasıdır. Geçen ay maaşını yettiremediği için kirayı bir hafta geç ödemiştir. Bu ay küçük çocuğunun sı sık hastalanması nedeniyle ilaçlara bir hayli fazla para harcamıştır. Bu gidişle yine kirayı zamaninda yatıramayacakttr.

Lider mahkemeyi yöneten hâkim rolüne bürünür. Mahkemeye neden olan durumu salona yüksek sesle okur.

"Davacı Ahmet Bey yanında çalışan Serkan Beyin geçen hafta cumartesi günü kasadan 300 TL çaldığını iddia etmektedir. Davalı olan Serkan Bey kasadan kendisine ait olmayan hiçbir şeyi almadı̆̆ını belirtmektedir. Olayın yaşandığı güne ait güvenlik kameralarının görüntülerinin silinmiş olduğu tespit edilmiştir. Olayı kimin yaptığı ile ilgili hiçbir delil yoktur. Yasalar suçlu bulunması durumunda Serkan beyin 1 ile 10 yll arasında hapis cezası alabileceğini belirtmektedir. Cezanın ne kadar olacağı jüri üyelerinin görüşlerine göre hâkimin vereceği kararla belli olacaktır."

Metin okunduktan sonra lider sırası ile ilgililerin kendilerini savunmalarını ister. 
Davacı, davalı, davacı avukatı, davalı avukatı...

İlgilileri dinleyen jüri üyelerine kendi aralarında durumu tartışmaları için süre verilir. Jüri üyelerinin Serkan Bey ile ilgili sırasıyla fikirlerini belirtmeleri istenir. Tüm üyeler fikirlerini beyan ettikten sonra hâkim olaya ilişkin yeni bilgileri paylaşır.

"Davacı Ahmet Bey işlek bir cadde üzerinde bulunan bir ayakkabı dükkânının sahibidir. Davalı Serkan Bey 5 yıldır Ahmet Beyin dükkânında çalışan bir elemandır. Ahmet Bey çalışanı Serkan Beyin performansını artırmak için satılan her ayakkabının 5 TL'sini ona vermektedir. Bu iş yerinde normal zamanlarda günlük ortalama 15 ayakkabı satılmaktadır. Buna karşıllk olarak Ahmet Bey Serkan Beye o günlerde 75 TL ekstra ödeme yapmaktadır. Dava konusu olan olayın yaşandiğı gün ise diğer günlerden farklı olarak 75 adet ayakkabı satıldı̆̆ tespit edilmişstir. Serkan Beyin satılan ayakkabı başına aldığ 5 TL dikkate alınacak olursa Ahmet beyin ona 375 TL ödemiş olmasl gerekmektedir. Ancak Ahmet Bey o gün de Serkan Beye yine 75 TL ödeme yapmıştır. Ayrıca gizli bir tanık mahkemeye verdiği ifadede o gün Serkan Beyi parayı kasadan alırken gördüğünü belirtmişstir."

Hâkim bu bilgiyi verdikten sonra yeniden tarafları kendilerini savunmaları için süre tanır. Verilen sürenin ardından sırası ile davacı, davalı, davacı avukatı, davalı avukatı konuşturulur.

Ardından jüri üyelerinin görüşleri alınır.

Hâkim davacı ve davalı arasında yapılan işs sözleşmesini okur.

\section{İ̧̧ Sözleşmesi:}

"Serkan Bey her gün 14 saat çalışacaktır. Serkan Bey 1 aylık çalışmasıının karşıllı̆̆ında 1500 TL maaş alacaktır. İ̧ yerinde yapılan satışların fazla ya da az olması durumunda maaşında herhangi bir değişiklik olmayacaktır."

Hâkim bu bilgiyi paylaştıktan sonra yine tarafların kendilerini savunmasını ister.

Son olarak jüri üyelerinden Serkan Bey hakkında bir karar vermeleri istenir.

Hâkim jürinin verdiği kararların aksi yönde bir karar vererek ahlaki ikilem oluşturur.

\section{Değerlendirme-Tartışma:}

4.Etkinlik: Öğrenciler çemberde toplanır. Lider aşağıdaki soruları sorarak öğrencilerin görüşlerini alır.

1- Bu hikâye gerçek olsaydı kimin yerinde olmak istemezdiniz? Neden?

2- Sizce bu hikâyede suçlu olan kimdir? Neden?

3- Bu hikâyedeki adaletsizlikler nelerdir?

4- Hâkimin verdiği karar sizce doğru mu? Neden?

5- Hâkim siz olsaydınız bu davayı adil bir şekilde nasıl sonuçlandırırdınız?

\section{Uygulama Sürecinden Görüntüler}

"Mahkeme Salonu” oturumu, hazırlık çalışmaları, 2.etkinlikten görüntüler; öğrenciler adalet kavramına ilişkin karışık olarak verilen yap-boz parçalarını birleştirmeye çalışıyor. 


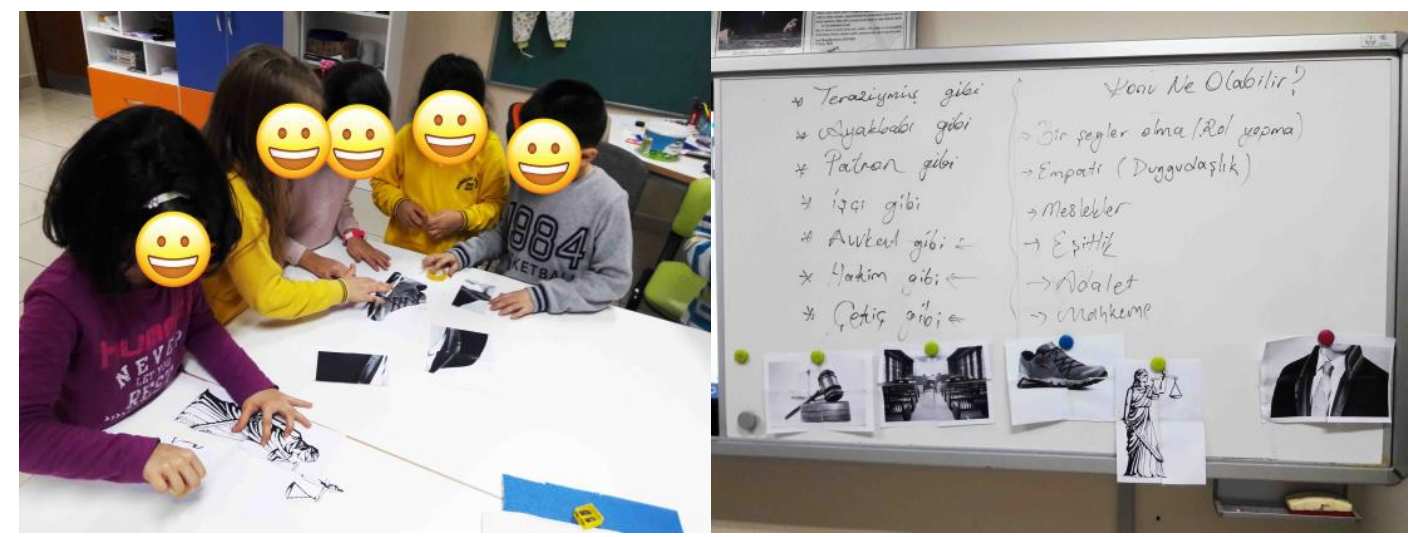

"Mahkeme Salonu” oturumu, canlandırma aşaması, 3.etkinlikten görüntüler; öğrenciler bir mahkeme salonu planına göre oturmuş, lider hâkim rolünde etkinliğe girmiş durumda.

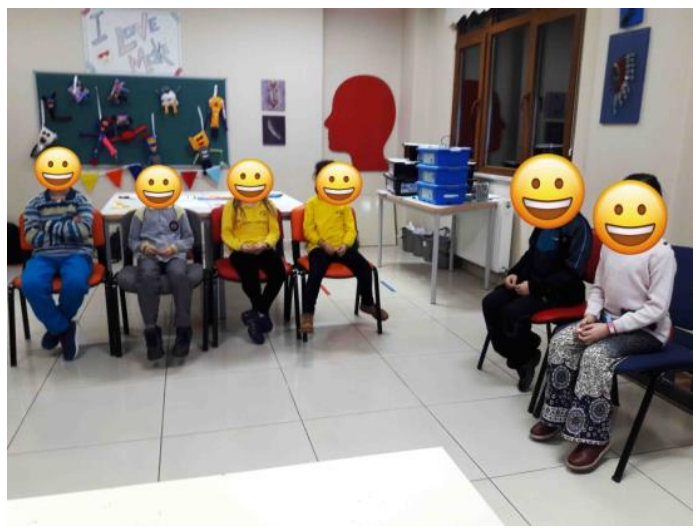

“Adalet mi, Eşitlik mi?” oturumu, canlandırma aşaması, 3. etkinlikten görüntüler; öğrencilerden biri ebeveyn diğeri çocuk rolünde, çocuk kendisine haksızlık yapıldığına ebeveynini ikna etmeye çalışıyor.

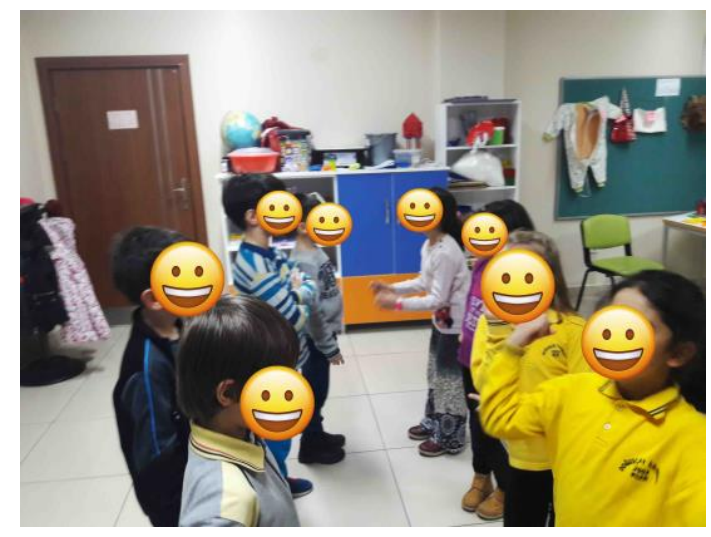

“Adalet mi, Eşitlik mi?” oturumu, canlandırma aşaması, 4. etkinlikten görüntüler; lider öğretmen rolünde, sınıf içerisinde meydana gelen bir örnek olay canlandırılıyor. 


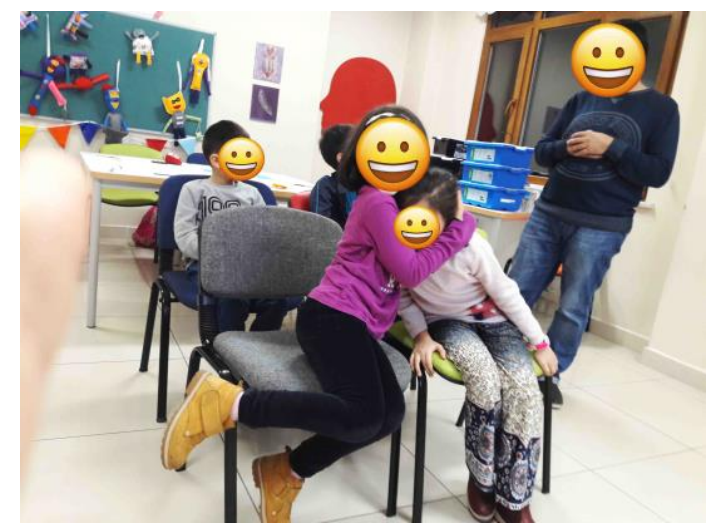

"Adil Paylaşım” oturumu, hazırlık çalışmaları, 1.etkinlikten görüntüler; öğrenciler liderin yönergesine göre 2, 4, 6 ve 8 kişi birleşerek bir pasta oluşturmaya çalışıyor. Pasta bir sonraki etkinliğin ana figürü olduğu için bu şekilde dikkat çekiliyor.

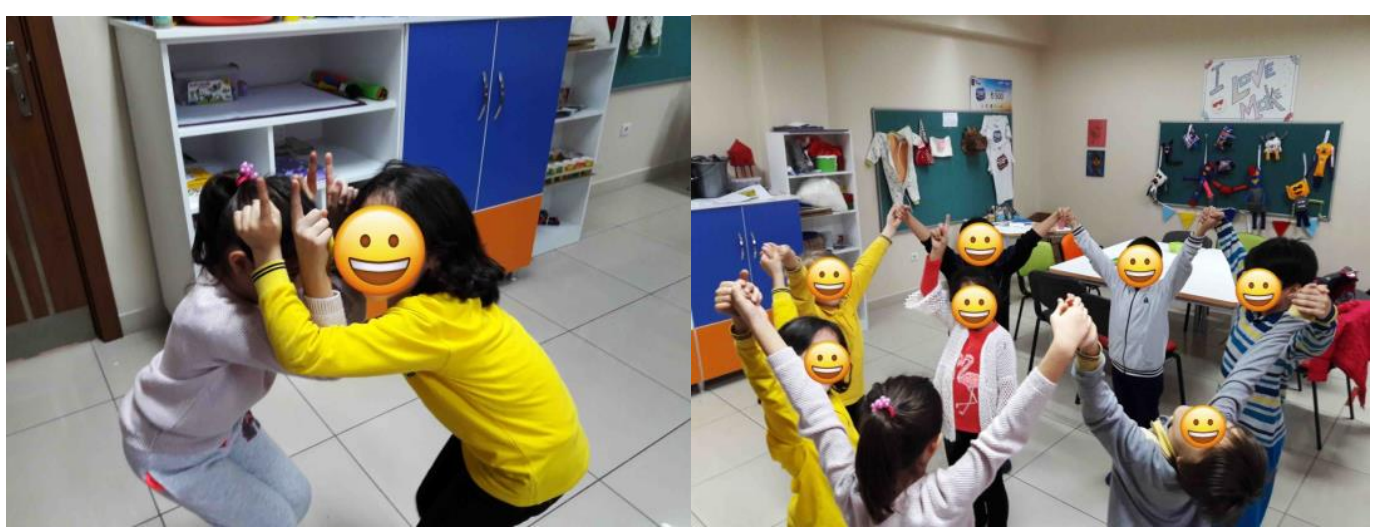

"Haksızlıklar” oturumu, canlandırma aşaması, 2.etkinlikten görüntüler; öğrenciler arkadaşlarının daha önceden uğradıkları bir haksızlığın yazılı olduğu kartları okuyor, devamında bu olayların canlandırması yapılarak çözüm önerileri sunmaları sağlanıyor.

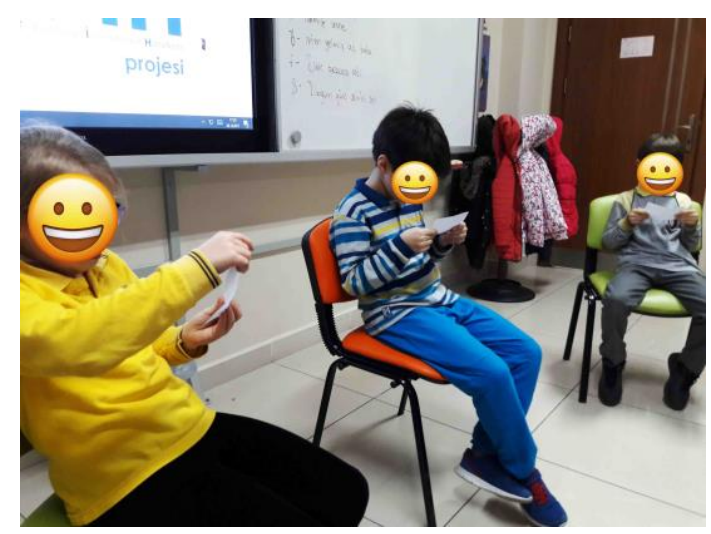

"Daha Çok Adalet" oturumu hazırlık çalışmaları, 1. etkinlikten görüntüler; öğrenciler arkadaşlarının bedenini bir kukla gibi hareket ettirerek anahtar kelimeleri buldurmaya çalışıyorlar. 


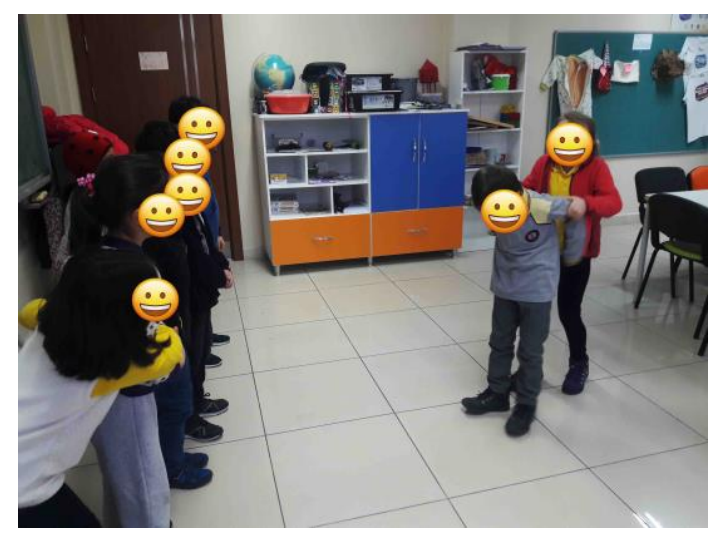

"Daha Çok Adalet” oturumu, canlandırma aşaması, 2. etkinlikten görüntüler; öğrenciler çomak kukla hazırlıyor ve hazırladıkları kuklalar ile bir adaletsizliği anlatan doğaçlama sahne gösterilerini sunuyor.

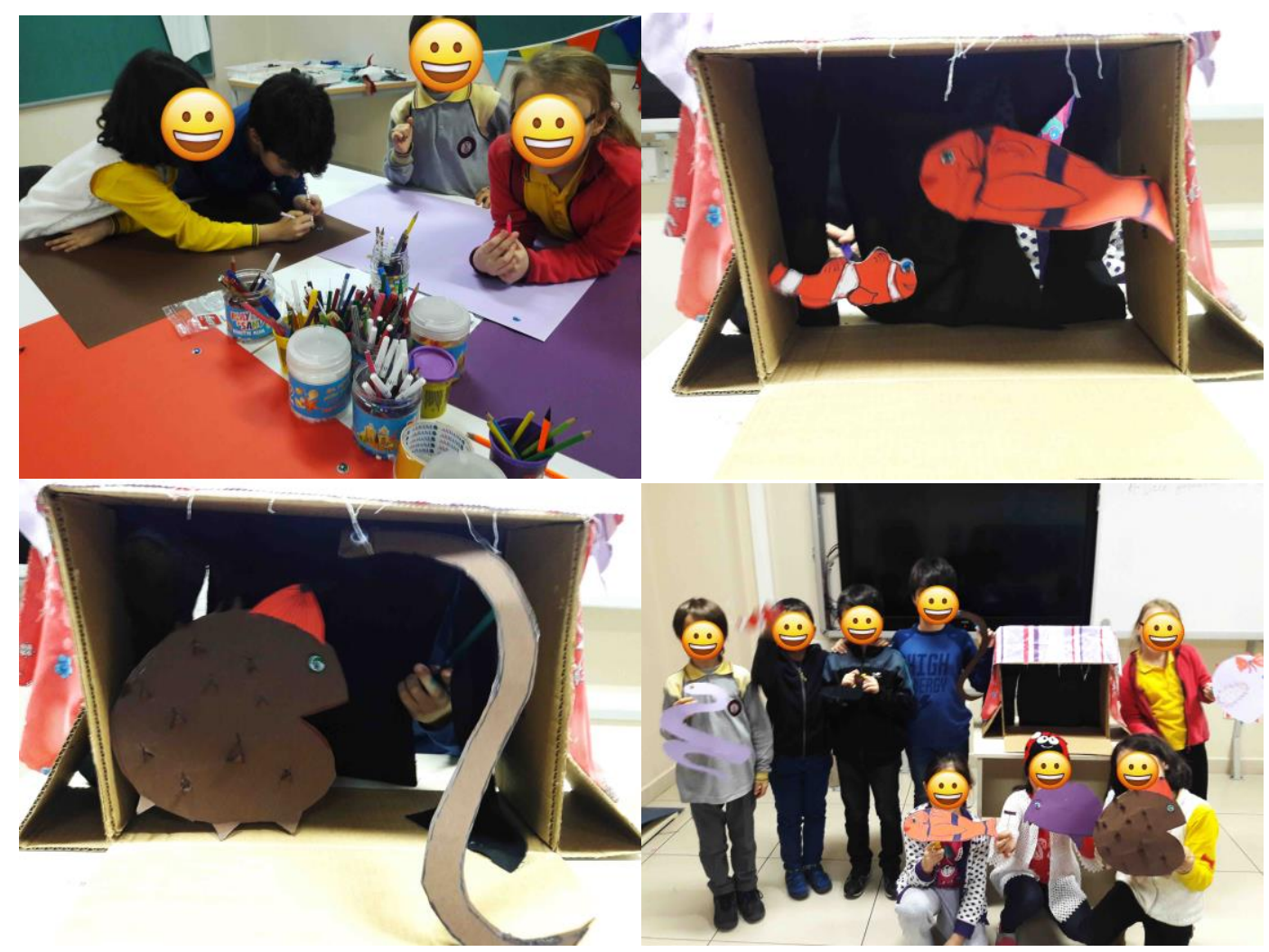

